\title{
Ribosomes act as cryosensors in plants
}

\author{
David Guillaume-Schöpfer ${ }^{1}$, Katja E. Jaeger ${ }^{1,2}$, Feng Geng ${ }^{1}$, Fabrizio G. Doccula ${ }^{3}$, Alex Costa ${ }^{3}$, \\ Alex A. R. Webb ${ }^{4}$ and Philip A. Wigge ${ }^{1,2,5 *}$ \\ ${ }^{1}$ Sainsbury Laboratory, University of Cambridge, Cambridge, CB2 1LR, United Kingdom. \\ ${ }^{2}$ Leibniz-Institut für Gemüse- und Zierpflanzenbau, Theodor-Echtermeyer-Weg 1, 14979 Großbeeren, Germany. \\ ${ }^{3}$ Department of Biosciences, University of Milan, 20133 Milan, Italy. \\ ${ }^{4}$ Department of Plant Sciences, University of Cambridge, Cambridge CB2 3EA, United Kingdom. \\ ${ }^{5}$ Institute of Biochemistry and Biology, University of Potsdam, 14476 Potsdam, Germany. \\ *Correspondence to: wigge@igzev.de
}

Cold temperatures are a threat to temperate plants, and Arabidopsis thaliana has acquired an adaptive gene expression network controlled by CBF transcription factors. The CBFs are sufficient to enable plants to survive otherwise lethal subzero temperatures. Constitutive CBF expression causes delayed flowering and stunted growth, and plants have evolved the ability to restrict CBF expression to occur only in the cold. This allows plants to anticipate likely freezing events and selectively deploy cold tolerance. The mechanism by which cold stress is sensed is however unknown. Here we show that protein translation rates in plants are proportional to temperature, and reduced translation rates trigger a rise in intracellular free calcium that activates the CAMTA transcription factors, and these directly activate cold-induced gene expression.

Freezing stress is a major threat to temperate plants, and Arabidopsis thaliana has evolved an adaptive transcriptional response activated by the C-REPEAT BINDING FACTOR1-3 (CBF1-3) AP2-type transcription factors, enabling survival of otherwise lethal subzero temperatures (Jaglo-Ottosen et al., 1998). Constitutive expression of CBFs however greatly reduces growth, and plants have evolved a pathway to restrict CBF expression to low temperatures (Jaglo-Ottosen et al., 1998). Activation of the CBFs by cold requires the activity of the CALMODULIN-BINDING

TRANSCRIPTION ACTIVATOR (CAMTA) 1, 2, 3 and 5 genes (Kim et al., 2013; Ohama et al., 2015). The CAMTAs are activated by $\mathrm{Ca}^{2+}$ sensing calmodulins (Bouché et al., 2005), and calcium levels rise during cold stress (Plieth et al., 1999; Monroy et al., 1993; Knight et al., 1996; Berberich and Kusano, 1997; Tähtiharju et al., 1997; Yamazaki et al., 2008). The cryosensory mechanism in this pathway is however unknown. Here we show that ribosome translation rates provide the initial temperature sensing events necessary for the activation of the cold stress response.

\section{Translation rate is proportional to temperature in plants \\ Protein synthesis by} ribosomes is a key cellular process, and the translation elongation rate is proportional to temperature in $E$. coli (Farewell and Neidhardt, 1998). To see if translation rates in plants are temperature-dependent, we measured the rate of protein synthesis using a cell-free system coupled to a Luciferase assay. This shows that translation efficiency increases strongly between $4{ }^{\circ} \mathrm{C}$ and $22{ }^{\circ} \mathrm{C}$ (Fig. 1A). We confirmed this effect by measuring protein levels (Supp. Fig. 1A).

To

determine if temperature impacts translation globally in the cell, we assayed incorporation of the aminonucleoside puromycin in de novo synthesised peptides (EK et al., 2009). As expected, inhibiting 80S ribosomes sharply decreases translation (Fig. 1B). The results confirm that protein synthesis rates are proportional to temperature in plants (Fig. 1C). Temperature does not affect puromycin uptake (Fig. 1D, Supp. Fig. 1B), confirming the direct kinetic link between temperature and ribosome processivity in plants.

Translation declines rapidly in the cold, comparable to the effect of $30 \mu \mathrm{M} \mathrm{CHX}$, consistent with the effect of temperature being direct (Fig. 1C,E). Translation rates begin to recover after 4 hours in the cold, indicating that acclimation mechanisms exist to enable some essential protein synthesis (Fig. $1 \mathrm{C}, \mathrm{E})$.

Reducing ribosomal activity induces early cold stress signalling Since protein synthesis rates are proportional to temperature, we tested if translation rates provide a mechanism to sense cold stress. Strikingly, slowing down translation using $\mathrm{CHX}$ is sufficient to rapidly induce the coldresponsive $p C B F 2:: L U C$ reporter at room temperature, resembling the cold response (Fig. 2A,B), consistent with previous observations (Zarka et al., 2003; Berberich and Kusano, 1997). The response to $\mathrm{CHX}$ is specific, since later responding cold genes such as COR15a are not induced (Fig. 2B).

To determine if protein translation rates control the global 
A

16000

B

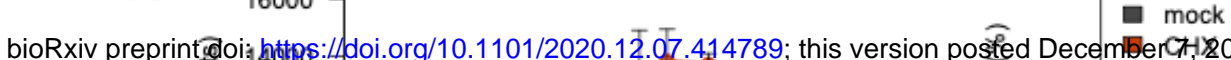
(which was not crrtified by peer review) is the authorffunder, who has granted bioRxive licensektendisplay the preprint
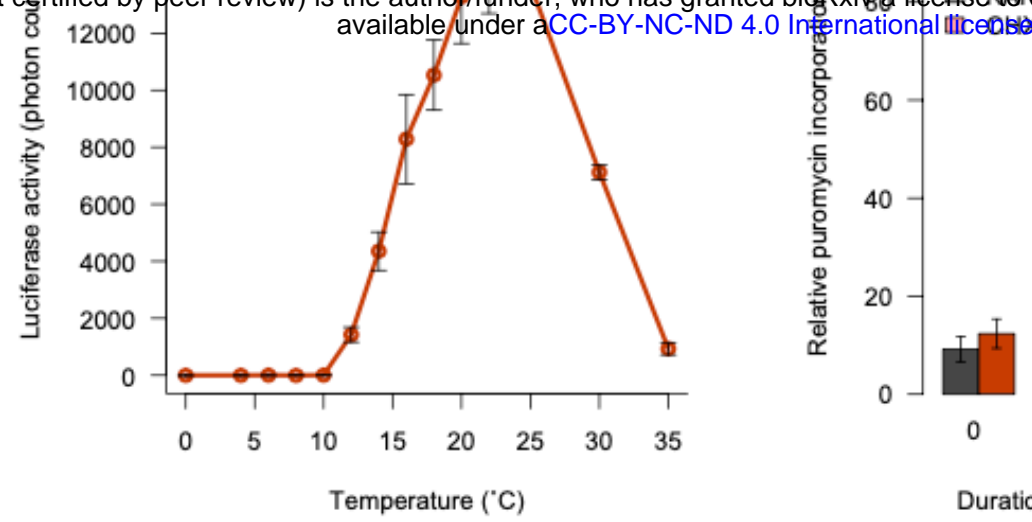

+ KAN

C

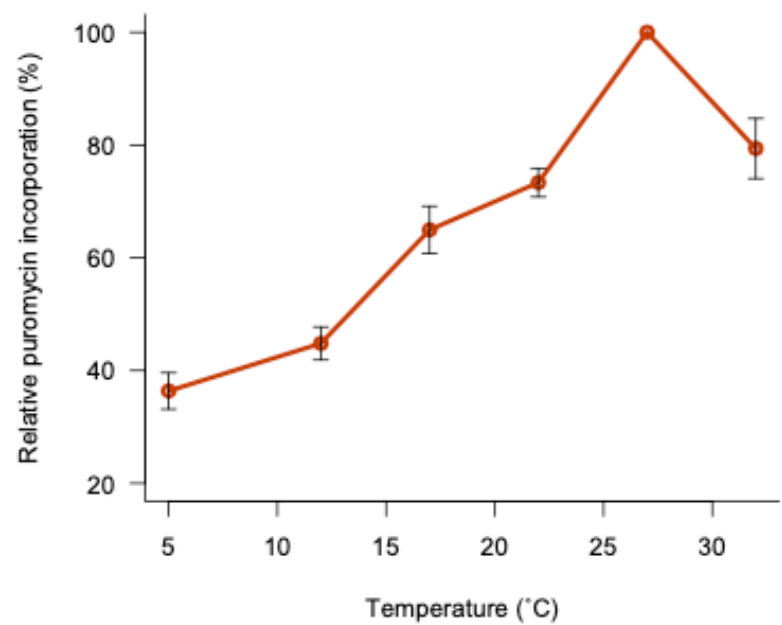

D Duration of puromycin treatment (minutes)

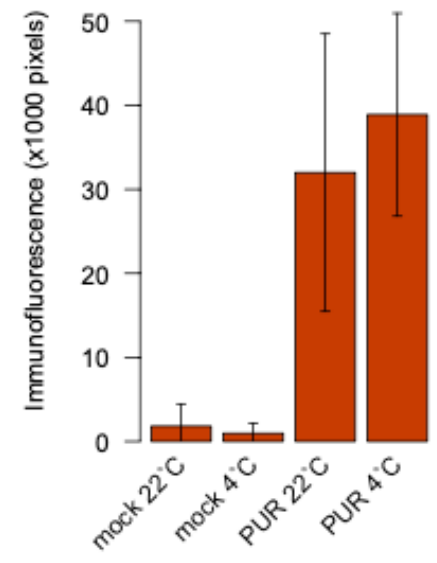

$\mathbf{E}$

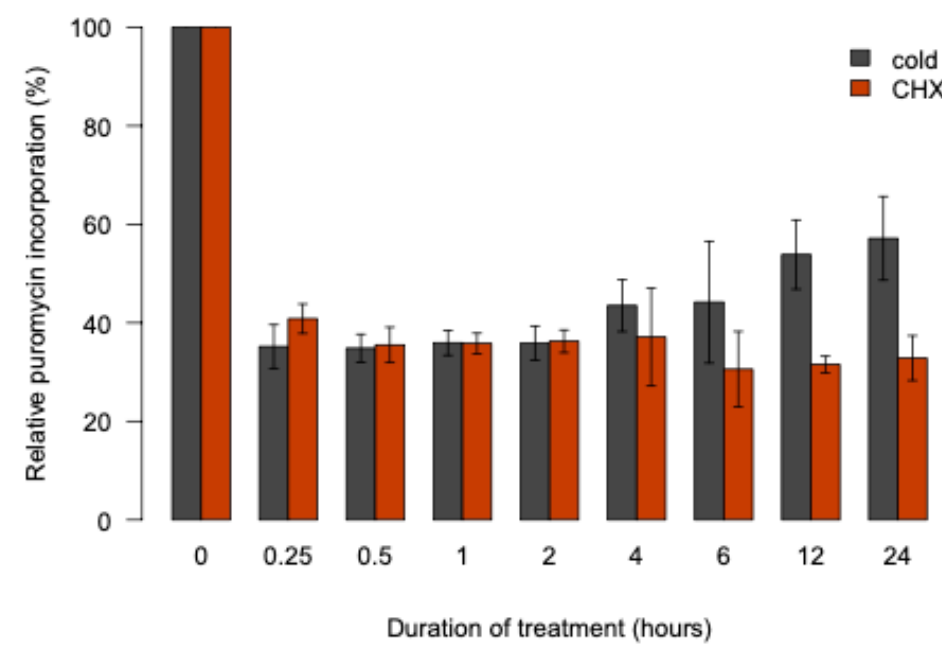

Figure 1: Translation rate is proportional to temperature.

A: Luminescence from luciferase synthesised in vitro at a range of temperatures (4 replicates). B, C, E: Quantification of in vivo translation in Arabidopsis seedlings ( $\geq 3$ replicates, $10-15$ seedlings each). B: Validation of the SUnSET assay. Seedlings were treated with $150 \mu \mathrm{M}$ puromycin (PUR) following 60minute incubations in $\mathrm{CHX}$ and/or kanamycin (KAN) at $30 \mu \mathrm{M}$ or $0.1 \%$ DMSO (mock). C: Low temperatures reduce protein synthesis in vivo. Assays were performed five days after transferring $22^{\circ} \mathrm{C}$-grown seedlings to the indicated temperatures. D: Low temperatures do not inhibit PUR uptake. Intracellular PUR was detected by immunofluorescence microscopy in seedlings at $4^{\circ} \mathrm{C}$ or $22^{\circ} \mathrm{C}$ (7 replicates). $\mathrm{E}$ : Cold and $\mathrm{CHX}$ cause rapid translational repression. Seedlings were treated with $0.1 \%$ DMSO at $22^{\circ} \mathrm{C}$ (mock) or $4^{\circ} \mathrm{C}$ or with $30 \mu \mathrm{M} \mathrm{CHX}$ at $22^{\circ} \mathrm{C}$ for 0 to 24 hours. PUR incorporation was normalised to mock controls. For all experiments, error bars indicate standard deviation. 
A

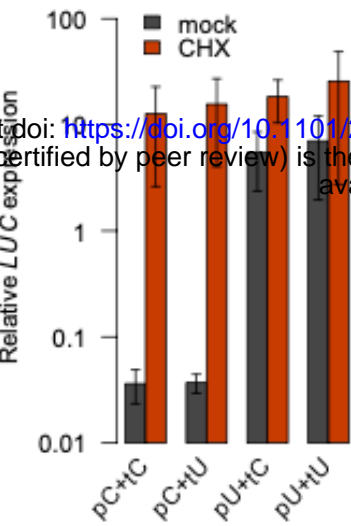

C

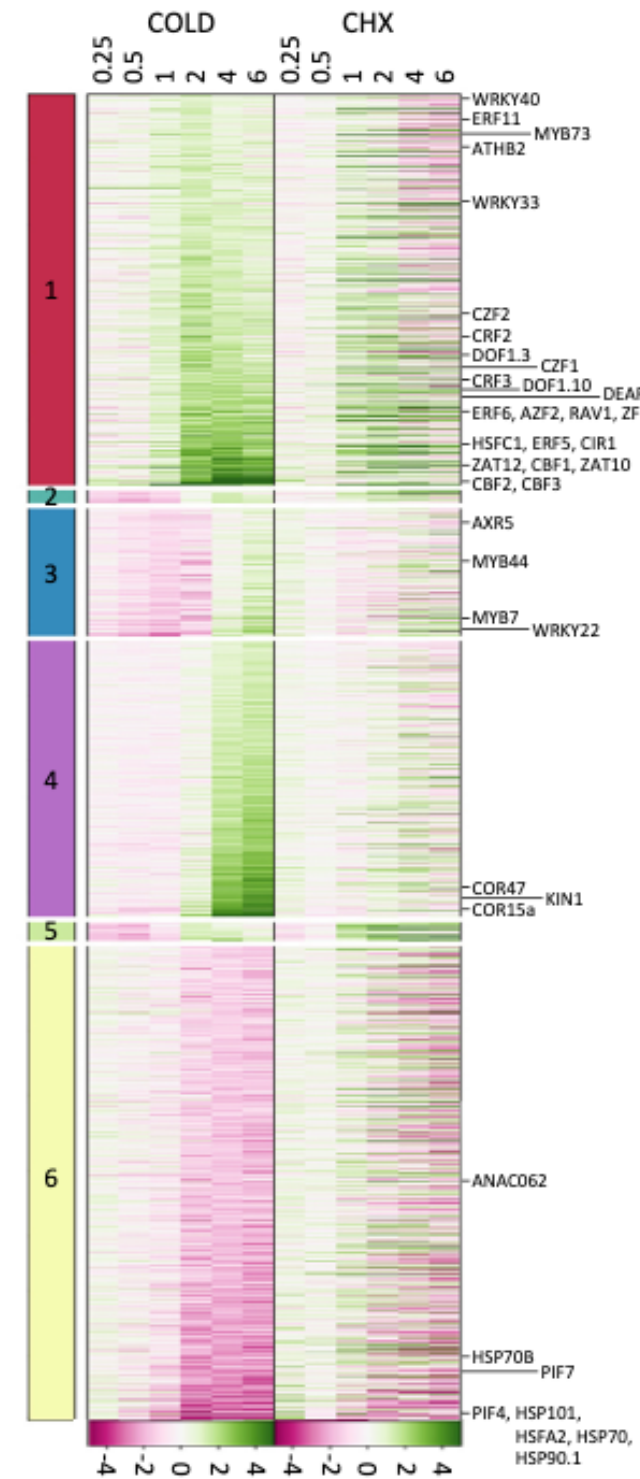

B

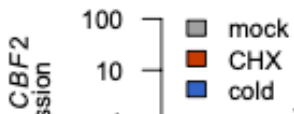

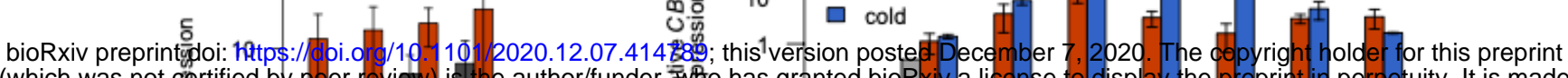
(which was not certified by peer review) is the author/funder, wiso has granted bioR xiv a license to display the preprint in perpetuity. It is made ailable under ace-BY-NC-ND开. International license.

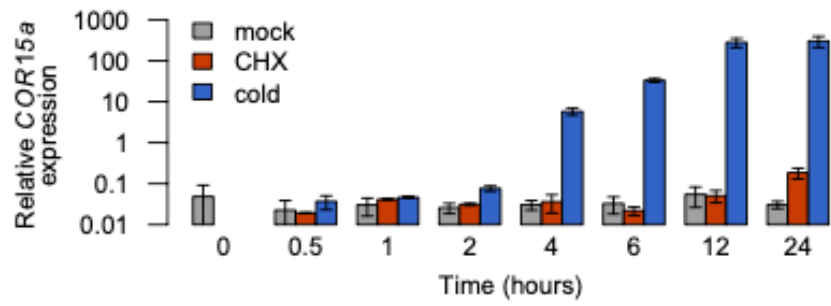

D
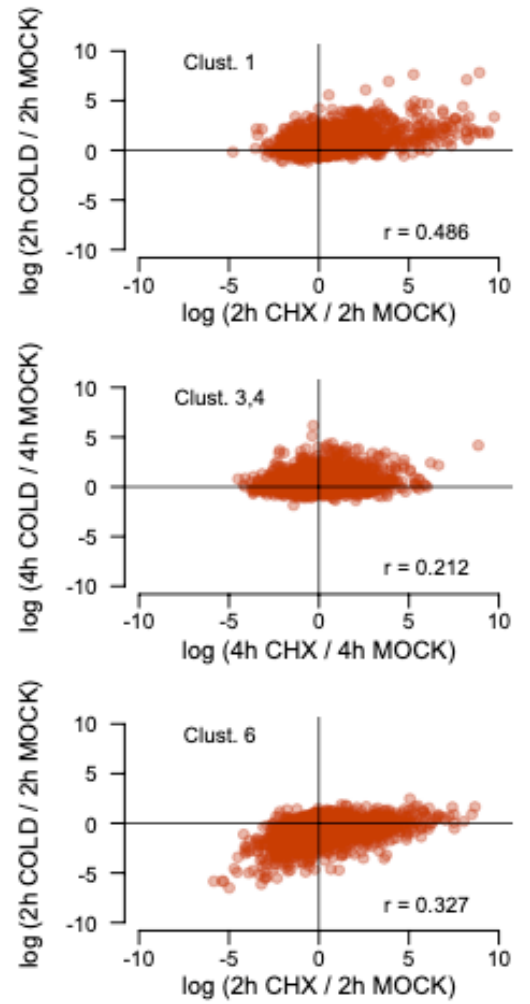

$\mathbf{E}$

\begin{tabular}{ccc}
\hline Motif & $\begin{array}{c}\text { Description } \\
\text { (Target) }\end{array}$ & $\begin{array}{c}\text { p- } \\
\text { value }\end{array}$ \\
\hline TTTGACTIIT & $\begin{array}{c}\text { W-box } \\
\text { (WRKY) }\end{array}$ & $1 \times 10^{-23}$ \\
ACGCGTTTTC & $\begin{array}{c}\text { CAM-box } \\
\text { (CAMTA) }\end{array}$ & $1 \times 10^{-20}$ \\
GCCACGTG & $\begin{array}{c}\text { G-box } \\
\text { (Group B } \\
\text { bHLH) }\end{array}$ & $1 \times 10^{-3}$ \\
\hline
\end{tabular}

Figure 2: Cold signalling is activated by reduced ribosome activity.

A: $\mathrm{CHX}$ activates the $C B F 2$ promoter. Expression of luciferase (LUC) driven from CBF2 or UBQ10 promoter $(\mathrm{pC}, \mathrm{pU})$ and terminator $(\mathrm{tC}, \mathrm{tU})$ sequences in Arabidopsis seedlings treated for 2 hours with $\mathrm{CHX}(30$ $\left.\mu \mathrm{M}, 22^{\circ} \mathrm{C}\right)$ or mock treatment $\left(0.1 \% \mathrm{DMSO}, 22^{\circ} \mathrm{C}\right)$ (four pools of 4-6 selected T1 seedlings). B: $\mathrm{CHX}$ induces CBF2 but not COR15a expression. $\mathrm{CHX}$, mock and cold $\left(0.1 \%\right.$ DMSO, $\left.4^{\circ} \mathrm{C}\right)$ treatments were carried out for 0 to 24 hours (3 replicates, 10-15 seedlings each). Error bars indicate standard deviation
(A, B). C: $\mathrm{CHX}$ induces an early cold-responsive cluster of genes. RNA-seq of seedlings after $\mathrm{CHX}$, mock or cold treatments for 0.25 to 6 hours. Genes were hierarchically clustered according to their temporal pattern of cold induction. Colours indicate log2 fold-changes in expression relative to mock controls and genes of interest are annotated. D: Correlation between cold- and CHX-responsive transcriptomes for key clusters. Pearson correlation coefficients are indicated. E: Top three motifs enriched in promoters upregulated by 1 -hour $\mathrm{CHX}$ treatment. 
response to cold stress, we compared the cold- and CHXresponsive transcriptomes over a $6 \mathrm{~h}$ time-course. Clustering of the coldresponsive genes reveals three major categories of response (Fig. $2 \mathrm{C})$. Cluster 1 contains genes activated by $1-2 \mathrm{~h}$ of cold (earlyinducible genes), including $C B F 1$, $C B F 2$ and $C B F 3$, and other transcription factors previously shown to respond rapidly to cold such as ZAT10, ZAT12, ZF and HSFC1 (Park et al., 2015). Clusters 3 and 4 are activated at 4-6 h of cold and include COR15a and COR47. The majority of genes in Cluster 1 are rapidly induced by $\mathrm{CHX}$ treatment, whereas this is not the case for Clusters 3 and 4 (Fig. $2 \mathrm{C}, \mathrm{D})$. Cluster 6 contains genes that are repressed by cold, including many heat-inducible genes such as HSP70, HSP101 and HSFA2, and many of these are repressed by CHX (Fig. 2C,D). CHX therefore activates the early cold-responsive transcriptional programme. Accordingly, genes induced after one hour of CHX treatment are enriched for promoter motifs targeted by transcription factors involved in cold signalling (Fig. 2E) (Doherty et al., 2009; Kidokoro et al., 2009; Lee and Thomashow, 2012; Kim et al., 2013; Park et al., 2015).

\section{Activation of cold- and CHX- responsive genes is mediated by CAMTAs}

Cold-mediated $\quad C B F$ expression is dependent on the CAMTA family of transcription factors (Kim et al., 2013; Kidokoro et al., 2017), and we find that this is also the case for CHX (Fig. 3A). This suggests that CHX-induced $C B F$ expression acts via the same pathway as cold stress. The CBF regulon is gated by the circadian clock, and we observe that PSEUDO-RESPONSE

REGULATOR 5, 7 and 9 (PRR5, 7 and 9) regulate $C B F 2$ inducibility by CHX (Fig. 3B). CBF2 expression is also more responsive to $\mathrm{CHX}$ at the beginning of the day, as has been described for the cold response, consistent with the CHX pathway acting through the same pathway as the cold stress signalling pathway (Supp. Fig. 2).

Since CHX and cold induction of $C B F 2$ is dependent on CAMTAs, we investigated whether these factors activate the cold transcriptome directly. Using epitope-tagged proteins complementing the camtal23 mutant (Supp. Fig. 3A,B), we performed ChIP-seq on CAMTA1, 2 and 3 in response to either cold or CHX treatment. Consistent with a direct role in activating early coldresponsive genes, the binding of these transcription factors is rapidly induced by both cold and CHX (Fig. $3 \mathrm{C}, \mathrm{D})$ and many of the genes in Cluster 1 are bound (Fig. 3C,F,G). CAMTAs also bind to the promoters of many genes in Clusters 3, 4 and 6 , suggesting that they may also contribute to the regulation of late cold-responsive genes, which are strongly bound by CBF2 (Supp. Fig. 3C,D,E). We find 1141 genes where the binding of CAMTA1, 2 or 3 at their promoters increases during both cold and CHX treatments (Fig. $3 \mathrm{E})$.

\section{Translational inhibition correlates with $C B F$ gene induction}

Since CHX has complex effects on the cell, we investigated whether its induction of the cold response is a specific consequence of its inhibition of ribosomes. Sampling a variety of translation inhibitors, we found a positive correlation between the degree of $C B F 2$ gene induction and the extent of translational inhibition (Fig. 4A). Inhibitors targeting different components of the translational machinery (Supp. Table 1) induce similar effects on the cold transcriptome, whereas terminating peptide elongation using puromycin has little effect (Fig. 4B).
To exclude the possibility that these chemicals activate the early cold response indirectly, we generated plants expressing the ribosomal protein point-mutant RPL36a $^{\mathrm{P} 56 \mathrm{Q}}$ (CYHrl, for cycloheximide resistance 1), which in budding yeast does not interact with CHX (Kawai et al., 1992). CYHrl seedlings can grow in the presence of CHX (Fig. 4C), demonstrating conserved resistance conferred by the RPL36a $a^{P 56 Q}$ mutation in plants. As expected, CYHrl plants are able to sustain protein synthesis when treated with CHX (Supp. Fig. 4), though some of ribosome inhibition still occurs as a result of two native RPL36a genes encoding CHX-binding proteins. CYHrl plants lose the ability to strongly induce $C B F 2$ gene expression in response to CHX, indicating that it is indeed the inhibition of ribosomal activity that transmits the cold signal (Fig. 4D).

\section{The cold signal is transmitted by a rise in cytosolic and nuclear calcium}

Our results indicate that the rate of translation provides a direct readout of ambient temperature, and we are able to mimic cold-induced reductions in ribosomal activity by the use of chemicals, enabling the direct activation of early coldresponsive genes. This raises the question of how this signal is propagated in the cell. In maize, interfering with $\mathrm{Ca}^{2+}$ signalling inhibits the induction of coldresponsive genes by CHX (Berberich and Kusano, 1997). We were able to recapitulate these findings in $A$. thaliana using the $\mathrm{Ca}^{2+}$ signalling inhibitors lanthanum, a competitive inhibitor of $\mathrm{Ca}^{2+}$-permeable channels, and BAPTA, a $\mathrm{Ca}^{2+}$ chelator. These chemicals reduce the activation of $C B F 2$ expression in response to cold and CHX treatments (Fig. 4E). Similar reductions in coldinducibility have been observed for other genes using $\mathrm{Ca}^{2+}$ signalling 
A

$\left.{ }^{20}\right]$ [

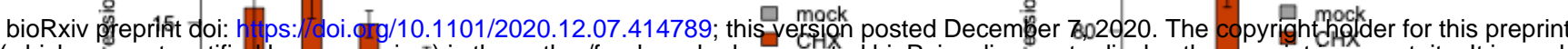
(which was not certified by peer review) is the author/funder, who has granted bioRxiv a licease to display the preprint in perpetuity. It is made

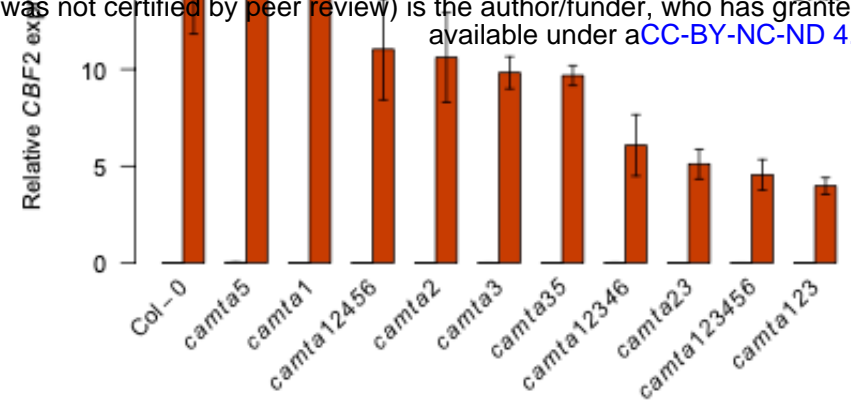

B

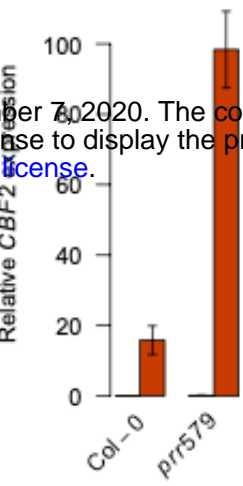

C

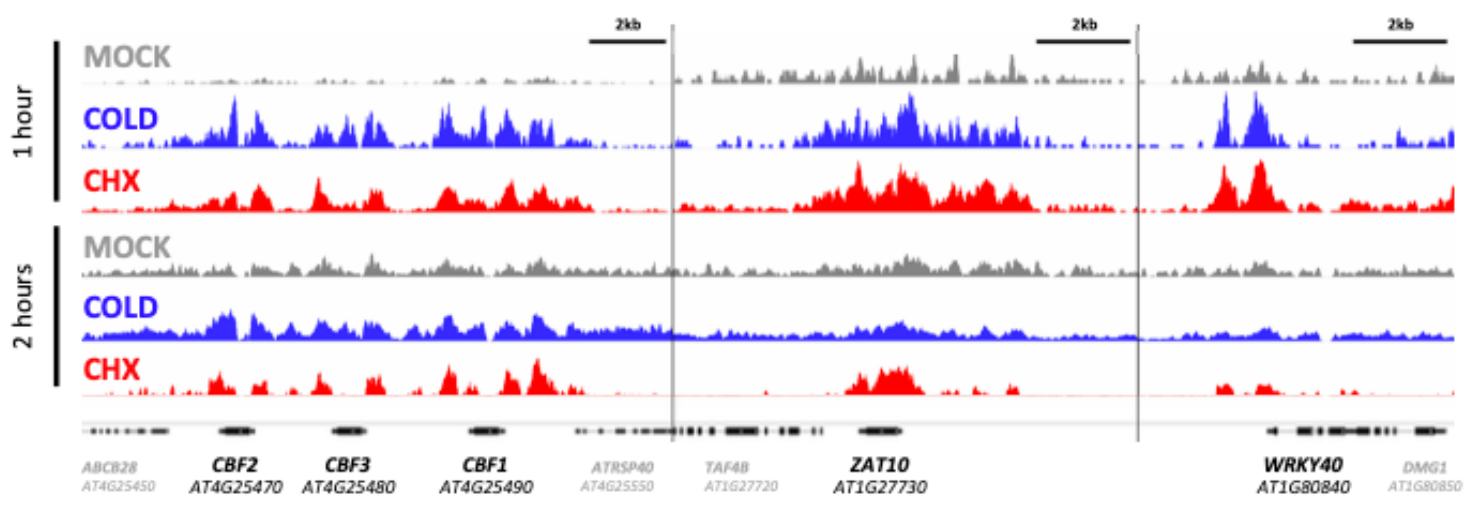

D

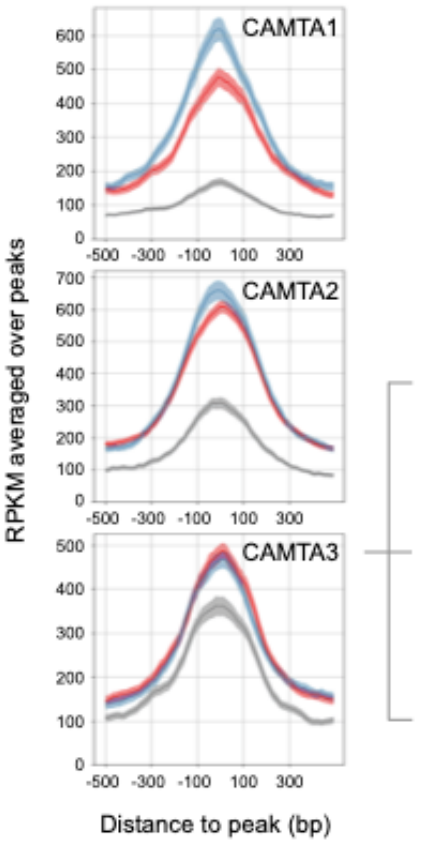

$\mathbf{E}$
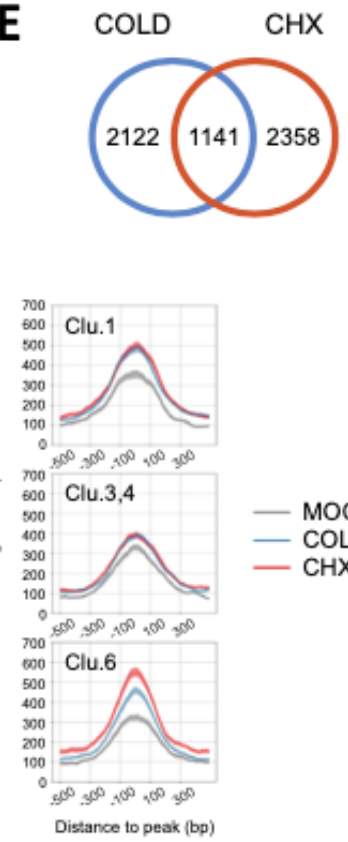

$\mathbf{F}$

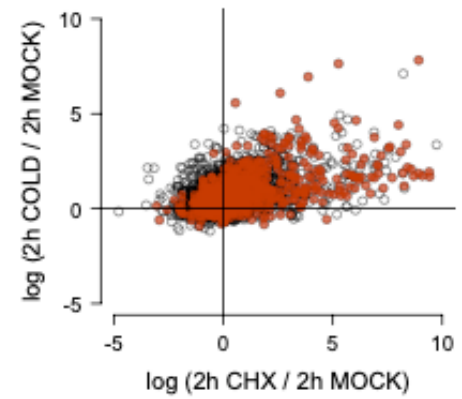

G

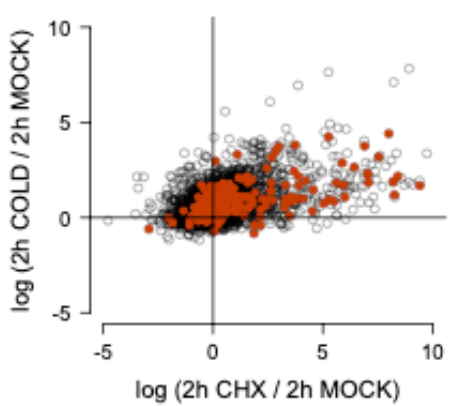

Figure 3: CAMTAs directly activate cold and $\mathrm{CHX}$ responsive genes

A, B: Arabidopsis camta (A) or prr mutants (B) were treated for 2 hours with $\mathrm{CHX}\left(30 \mu \mathrm{M}, 22^{\circ} \mathrm{C}\right)$ or mock treatment $\left(0.1 \%\right.$ DMSO, $\left.22^{\circ} \mathrm{C}\right)$. Error bars indicate standard deviation (3 replicates, 10-15 seedlings each). CG: ChIP-seq of CAMTA1, 2 and 3 in complemented camta123 seedlings after 1 or 2 hours of $\mathrm{CHX}$, mock or cold $\left(0.1 \% \mathrm{DMSO}, 4^{\circ} \mathrm{C}\right)$ treatments. C: Cold- and $\mathrm{CHX}$ associated binding of CAMTA2 at early cold-inducible genes CBF1, CBF2, CBF3, ZAT10 and WRKY40. D: Genome-wide pile-ups of CAMTA1, 2 and 3 after 1-hour treatments, and cluster-specific pile-ups of CAMTA3. E: More than a third of genes bound by CAMTAs at $4^{\circ} \mathrm{C}$ are also bound during $\mathrm{CHX}$ treatments at $22^{\circ} \mathrm{C}$. Numbers indicate genes at which there is an increase in occupancy of CAMTA1, 2 or 3 during 1 or 2 hours of treatments relative to mock controls. F, G: Many early cold-inducible genes are bound by CAMTAs. Log2 fold-changes in expression of genes from Cluster 1 during 2-hour $\mathrm{CHX}$ or cold treatments relative to mock treatments. Genes bound by CAMTA1, 2 or 3 in response to both cold and $\mathrm{CHX}(\mathbf{F})$ or during either treatment $(\mathbf{G})$ are indicated in red. 
bioRxiv preprint Api: https://doi.org/10.1101/2020.12.07.414789; this version BstedDeceember 7 , 2020 . The (which was not certified by peereview) is the author/funder, wholhas granted bioRxiv a license to display the preprint in perpetuity. It is made

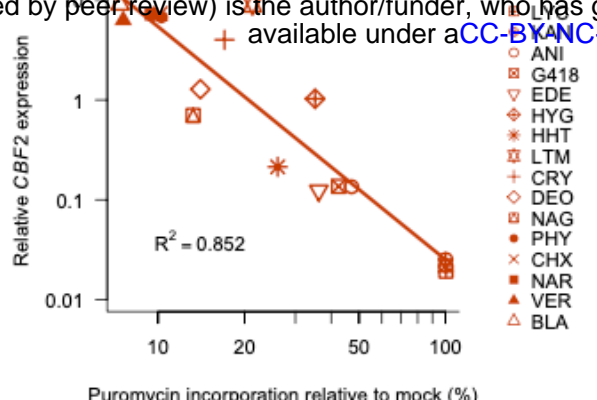

Puromycin incorporation relative to mock (\%)

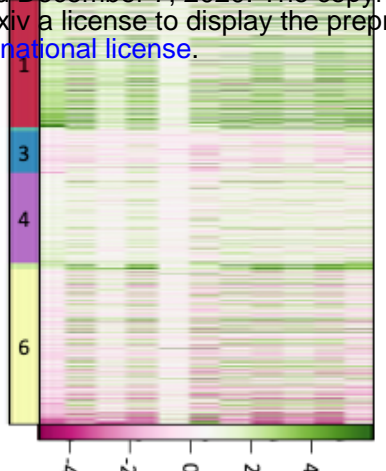

E

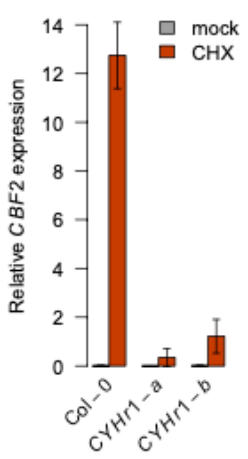

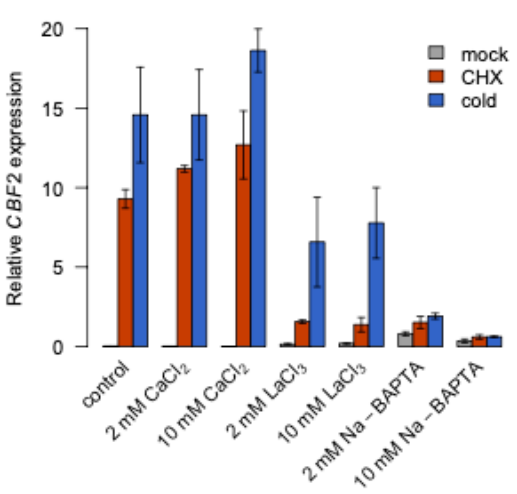

$\mathbf{F}$
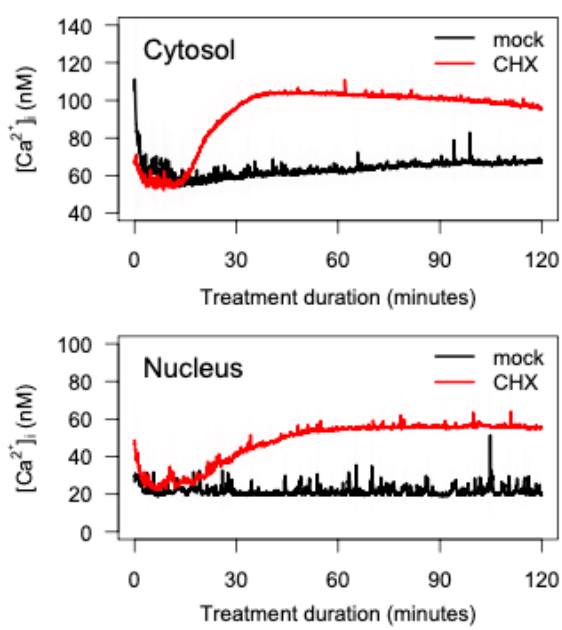

Figure 4: Ribosome-mediated cold gene activation involves calcium signalling.

A: Translational activity correlates with $C B F 2$ gene expression. Seedlings were treated with inhibitors $(30 \mu \mathrm{M}$, $22^{\circ} \mathrm{C}$ ) or mock treatment $\left(0.1 \% \mathrm{DMSO}, 22^{\circ} \mathrm{C}\right)$ for 1 or 2 hours for translation assays and expression analyses, respectively. B: RNA-seq of seedlings after 2 hours of inhibitor, mock or cold $\left(0.1 \% \mathrm{DMSO}, 4^{\circ} \mathrm{C}\right)$ treatments. BLA: blasticidin S, ANI: anisomycin, LTM: lactimidomycin, HYG: hygromycin B, VER: verrucarin A, NAR: narciclasine, PHY: phyllanthoside, NAG: nagilactone C, DEO: deoxynivalenol, CRY: cryptopleurine, LYC: lycorine, HHT: homoharringtonine, EDE: edeine A1, KAN: kanamycin, SBI: SBI-0640756, SIL: silvestrol, FUS: fusidic acid. PUR, EDE and FUS treatments in (B) were at $150 \mu \mathrm{M}$ as they do not induce CBF2 expression at $30 \mu \mathrm{M}$. Colours indicate log2 fold-changes in expression relative to mock controls, for clusters from Fig. 2. C: Growth assay of wild-type and
G
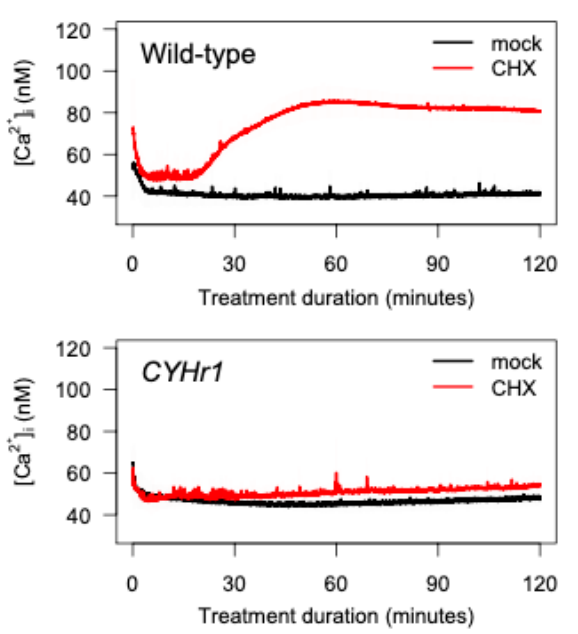

CYHr1 seedlings in the presence of $\mathrm{CHX}$ or mock treatment. D: $C B F 2$ induction by $\mathrm{CHX}$ is abolished in CYHr1 seedlings. Wild-type and $C Y H r 1$ seedlings were treated with $\mathrm{CHX}$ or mock treatment for two hours. E: Calcium signalling inhibitors block $C B F 2$ induction by cold and $\mathrm{CHX} . \mathrm{CaCl}_{2}$ : calcium chloride, $\mathrm{LaCl}_{3}$ : lanthanum chloride, Na-BAPTA: sodium BAPTA, control: media. Error bars indicate standard deviation for 3 replicates with 10-15 seedlings each (D, E). F: CHX triggers an increase in cytosolic and nuclear free calcium levels. G: The CHXinduced increase in intracellular calcium is abolished in CYHr1 seedlings. Intracellular free calcium levels were quantified luminometrically in seedlings expressing apoaequorin in a localised $(F)$ or ubiquitous $(G)$ manner, during 2-hour $\mathrm{CHX}$ or mock treatments. Shading indicates standard deviation for at least three biological replicates, each comprising a cuvette with 3 seedlings. 
inhibitors in plants (Monroy et al., 1993; Knight et al., 1996; Polisensky and Braam, 1996; Tähtiharju et al., 1997).

Targeting the $\mathrm{Ca}^{2+}$ reporter aequorin to the nucleus or cytosol (Supp. Fig. 5), we found that CHX causes a rise in cytosolic and nuclear free $\mathrm{Ca}^{2+}$ (Fig. 4F). We obtained similar results using the $\mathrm{Ca}^{2+}$ reporter Cameleon localised in the cytosol (Supp. Fig. 6A, Supp. Movie). Since the induction of early cold-responsive genes by $\mathrm{CHX}$ is attenuated in $\mathrm{CYHrl}$ plants, we investigated changes in $\mathrm{Ca}^{2+}$ levels during CHX treatment in this line. No significant increase in intracellular free $\mathrm{Ca}^{2+}$ was detected in these plants (Fig. 4G). These results indicate that $\mathrm{Ca}^{2+}$ is a signal for activation of the early cold response during translation inhibition. CAMTA transcription factors are regulated by $\mathrm{Ca}^{2+}$ sensing calmodulins (Bouché et al., 2005) and therefore provide a direct mechanism by which elevated nuclear free $\mathrm{Ca}^{2+}$ levels triggered by translation inhibition can activate early cold-responsive genes such as the $C B F \mathrm{~s}$. The $70 \mathrm{~S}$ ribosome inhibitor kanamycin triggers a distinct cytosolic $\mathrm{Ca}^{2+}$ signature, but it does not induce $C B F$ expression (Supp. Fig. 6B,C). This demonstrates that inhibiting cytosolic ribosomes generates a specific $\mathrm{Ca}^{2+}$ signal required for the activation of the early cold response.

Ribosome translation rates are also proportional to temperature in E. coli (Farewell and Neidhardt, 1998), and inhibiting translation in human cells also inactivates the heat shock response (Santagata et al., 2013), suggesting that ribosomes may have a broad role in providing thermosensory information. Since ribosomes must be active within the ambient temperature range of every organism, they are well suited to sense deviations from optimal temperature.

\section{References and Notes:}

Berberich, T. and Kusano, T. (1997). Cycloheximide induces a subset of low temperature-inducible genes in maize. Mol. Gen. Genet. 254: 275-83.

Bouché, N., Yellin, A., Snedden, W.A., and Fromm, $\mathrm{H}$. (2005). PLANT-SPECIFIC CALMODULIN-BINDING PROTEINS. Annu. Rev. Plant Biol. 56: 435-466.

Doherty, C.J., Van Buskirk, H.A., Myers, S.J., and

Thomashow, M.F. (2009).

Roles for Arabidopsis CAMTA transcription factors in cold-regulated gene expression and freezing tolerance. Plant Cell 21: 972_84.

EK, S., G, C., M, C., and P, P. (2009). SUnSET, a Nonradioactive Method to Monitor Protein Synthesis. Nat. Methods 6.

Farewell, A. and Neidhardt, F.C. (1998). Effect of temperature on in vivo protein synthetic capacity in Escherichia coli. J. Bacteriol.

Jaglo-Ottosen, K.R., Gilmour, S.J., Zarka, D.G., Schabenberger, $O$., and Thomashow, M.F. (1998). Arabidopsis CBF1 overexpression induces COR genes and enhances freezing tolerance. Science (80-. ). 280: 104-106.

Kawai, S., Murao, S., Mochizuki, M., Shibuya, I., Yano, K., and Takagi, M. (1992).

Drastic alteration of cycloheximide sensitivity by substitution of one amino acid in the L41 ribosomal protein of yeasts. J. Bacteriol. 174: 254-262.

Kidokoro, S., Maruyama, K., Nakashima, K., Imura, Y., Narusaka, Y., Shinwari, Z.K., Osakabe, Y., Fujita, Y., Mizoi, J., Shinozaki, K., and Yamaguchi-Shinozaki, K. (2009). The PhytochromeInteracting Factor PIF7 Negatively Regulates DREB1 Expression under Circadian Control in Arabidopsis. Plant Physiol. 151: 2046-2057.

Kidokoro, S., Yoneda, K., Takasaki, H., Takahashi, F., Shinozaki, K., and Yamaguchi-Shinozaki, K. (2017). Different ColdSignaling Pathways Function in the Responses to Rapid and Gradual Decreases in Temperature. Plant Cell 29: 760-774.

Kim, Y., Park, S., Gilmour, S.J., and Thomashow, M.F. (2013). Roles of CAMTA transcription factors and salicylic acid in configuring the low-temperature transcriptome and freezing tolerance of Arabidopsis. Plant J. 75: 364-376.

Knight, H., Trewavas, A.J., and Knight, M.R. (1996). Cold calcium signaling in Arabidopsis involves two cellular pools and a change in calcium signature after acclimation. Plant Cell 8: 489-503.

Lee, C. and Thomashow, M.F. (2012). Photoperiodic regulation of the $\mathrm{C}$-repeat binding factor ( $\mathrm{CBF}$ ) cold acclimation pathway and freezing tolerance in Arabidopsis thaliana.: 6-11.

Monroy, A.F., Sarhan, F., and Dhindsa, R.S. (1993). ColdInduced Changes in Freezing Tolerance, Protein Phosphorylation, and Gene Expression (Evidence for a Role of Calcium). Plant Physiol. 102: 1227-1235.

Ohama, N., Kusakabe, K., Mizoi, J., Zhao, H., Kidokoro, S., Koizumi, S., Takahashi, F., Ishida, T., Yanagisawa, S., Shinozaki, K., and Yamaguchi-Shinozaki, K. (2015). The transcriptional 
cascade in the heat stress response of Arabidopsis is strictly regulated at the expression levels of transcription factors. Plant Cell 28: 181-201.

Park, S., Lee, C.-M., Doherty, C.J., Gilmour, S.J., Kim, Y., and Thomashow, M.F. (2015). Regulation of the Arabidopsis CBF regulon by a complex low-temperature regulatory network. Plant J. 82: 193-207.

Plieth, C., Hansen, U.-P., Knight, H., and Knight, M.R. (1999). Temperature sensing by plants: the primary characteristics of signal perception and calcium response. Plant J. 18: 491497.

Polisensky, D.H. and Braam, J. (1996). Cold-shock regulation of the Arabidopsis $\mathrm{TCH}$ genes and the effects of modulating intracellular calcium levels. Plant Physiol. 111: 1271-9.

Santagata, S. et al. (2013). Tight coordination of protein translation and HSF1 activation supports the anabolic malignant state. Science 341: 1238303.

Tähtiharju, S., Sangwan, V., Monroy, A.F., Dhindsa, R.S., and Borg, M. (1997). The induction of kin genes in cold-acclimating Arabidopsis thaliana. Evidence of a role for calcium. Planta 203: 442 447.

Yamazaki, T., Kawamura, Y., Minami, A., and Uemura, M. (2008). CalciumDependent Freezing Tolerance in Arabidopsis Involves Membrane Resealing via Synaptotagmin SYT1. Plant Cell 20: 33893404.

Zarka, D.G., Vogel, J.T., Cook, D., and Thomashow, M.F. (2003). Cold induction of Arabidopsis CBF genes involves multiple ICE (inducer of CBF expression) promoter elements and a cold-regulatory circuit that is desensitized by low temperature. Plant Physiol.
133: $910-8$.

Acknowledgments: Funding: DGS was supported by a BBSRC Studentship (BB/L502327/1). FGD received a $\mathrm{PhD}$ fellowship from the University of Milan. AC received support from the PIANO DI SVILUPPO DI ATENEO 2017 from the University of Milan. PAW received support from the European Research Council (EC FP7 ERC 243140) and the Gatsby Charitable Foundation (GAT3273/GLB). PAW receives funding from the Leibniz Foundation. Author contributions: DGS conceived the experiments, performed most of the experiments and wrote the first draft of the manuscript; KEJ performed the ChIP-seq experiments; FG performed the bioinformatic analysis in collaboration with DGS; FGD performed the Cameleon experiments; AC, AARW and PAW conceived the experiments and assisted in writing the manuscript. Competing interests: Authors declare no competing interests. 


\section{Plant materials and growth conditions}

The camta1, camta2, camta3, camta23 and camta123 mutants were provided by Michael Thomashow (Kim et al., 2013) and comprise the following T-DNA insertions: SALK_008187, SALK_007027 and SALK_001152. The camta5, camta35, camta12346, camta12456 and camta123456 mutants were provided by Kazuko Yamaguchi-Shinozaki (Kidokoro et al., 2017) and include the following T-DNA insertions: SALK_108806, SALK_139868, SALK_001152, SALK_087870, SALK_134491 and SALK_078900. The prr579 mutant (prr5-11 prr7-11 prr9-10) was provided by Norihito Nakamichi (Nakamichi et al., 2005) and consists of T-DNA insertions SALK_064538, SALK_030430 and SALK_007551. The Col-0 pCaMV35S::APOAEQUORIN line was provided by Alex Webb (Xu et al., 2007), and the Col-0 pUBQ10-NES::YC3. 6 line was provided by Melanie Krebs (Krebs et al., 2012).

Seeds were surface-sterilised using ethanol or vapour-phase sterilisation (Clough \& Bent, 1998) and stratified in respective growth media in the dark at $4^{\circ} \mathrm{C}$ for 72 hours. Growth cabinets were maintained at $65 \%$ relative humidity and $170 \mu \mathrm{mol} / \mathrm{m}^{2} / \mathrm{s}$ light, unless specified otherwise, and as specified per experiment seedlings were grown at $20^{\circ} \mathrm{C}$ with a 12 -hour photoperiod or at $22^{\circ} \mathrm{C}$ with either continuous light, a 16-hour long-day photoperiod or an 8-hour short-day photoperiod.

For ChIP-seq, $A$. thaliana seedlings were grown for 8 days on 1-mm-pore nylon mesh rafts placed on half-strength MS medium (pH 5.7) with 0.8\% w/v agar (P1001, Duchefa) ('MS agar' hereafter) $\left(22^{\circ} \mathrm{C}\right.$ long days).

For Cameleon experiments, seedlings were grown for 6-7 days on vertical plates of MS agar supplemented with $0.1 \% \mathrm{w} / \mathrm{v}$ sucrose and $0.05 \% \mathrm{w} / \mathrm{v} \mathrm{MES}\left(22^{\circ} \mathrm{C}\right.$ long days, with Cool White Neon lamps at $\left.100 \mu \mathrm{mol} / \mathrm{m}^{2} / \mathrm{s}\right)$.

For gene expression analyses, SUnSET assays, seedlings were grown for 7-9 days in halfstrength Murashige-Skoog liquid medium ( $1 / 2 \times \mathrm{MS} ; 0.22 \% \mathrm{w} / \mathrm{v}$ Murashige-Skoog mix including vitamins; M0222, Duchefa) containing 0.05\% w/v MES (2-[N-morpholino]ethanesulfonic acid; 69892, Sigma), adjusted to $\mathrm{pH} 5.7$ and supplemented with $0.1 \% \mathrm{w} / \mathrm{v}$ glucose after autoclaving (' $1 / 2 \mathrm{MMG}$ medium' hereafter) $\left(22^{\circ} \mathrm{C}\right.$ long days, with the following exceptions: $22^{\circ} \mathrm{C}$ short days for Fig. $1 \mathrm{C}$, and $22^{\circ} \mathrm{C}$ continuous light for Figs. 2B, 3A, 3B, 4E). The seedlings were cultured in 12- or 6-well plates (657-160 and 665-180, Greiner Bio-One), with $1 \mathrm{~mL}$ or $2 \mathrm{~mL}$ of liquid medium per well, respectively, and sealed with Micropore tape. For aequorin-based calcium measurements, seedlings were grown in $1 / 2 \mathrm{MMG}$ for 8 to 12 days at $20^{\circ} \mathrm{C}$ with a 12-hour photoperiod.

For transformations and seed harvesting, $A$. thaliana plants were grown on Levington $\mathrm{F} 2$ soil (22 ${ }^{\circ} \mathrm{C}$ long days). Transgenic $A$. thaliana T1 and T2 seeds were stratified and grown for selection on MS agar supplemented with 50 to $100 \mu \mathrm{g} / \mathrm{mL}$ kanamycin.

\section{Temperature and chemical treatments}


Inhibitors were prepared as indicated in Table 1. Edeine A1 was provided by lan Brierley (University of Cambridge) and phyllanthoside, cryptopleurine, narciclasine, nagilactone $\mathrm{C}$ and silvestrol were provided by the Developmental Therapeutics Program of the National Cancer Institute $(\mathrm{NCl})$, National Institute of Health (NIH). Chemical treatments were performed by replacing the liquid medium with fresh $1 / 2 \mathrm{MMG}$ medium containing chemicals diluted to the specified concentrations. Cold shock treatments were performed by transferring plates to $4^{\circ} \mathrm{C}$ pre-cooled cabinets, at $170 \mu \mathrm{mol} / \mathrm{m}^{2} / \mathrm{s}$ light and $65 \%$ relative humidity.

For ChIP-seq samples, plants on MS agar were incubated at $4^{\circ} \mathrm{C}$ for four hours (CBF2 ChIPseq) or submerged with $30 \mu \mathrm{M} \mathrm{CHX}$ or $0.1 \% \mathrm{v} / \mathrm{v}$ DMSO (mock control) in deionised water and maintained at $22^{\circ} \mathrm{C}$ or $4^{\circ} \mathrm{C}$ for one or two hours (CAMTA ChIP-seq).

For SUnSET assays to measure in vivo translation (Schmidt et al., 2009), following temperature or chemical treatments, the media was supplemented with either 100 or $150 \mu \mathrm{M}$ puromycin (in $1 / 2 \mathrm{MMG}$; temperature-adjusted) and seedlings were harvested after 20 or 30 minutes of incubation.

For growth assays of Col- 0 and $C Y H r 1$ seedlings in the presence of $\mathrm{CHX}$, the $1 / 2 \mathrm{MMG}$ media was removed after two days of growth and replaced with fresh media containing $\mathrm{CHX}$ or DMSO to final concentrations of 3,10 or $30 \mu \mathrm{M}$ or $0.1 \% \mathrm{v} / \mathrm{v}$, respectively, and seedlings were imaged after seven days of growth $\left(22^{\circ} \mathrm{C}\right.$ long days).

Table 1: Inhibitors used in this study

\begin{tabular}{|c|c|c|c|c|c|}
\hline Chemical & Target & $\begin{array}{l}\text { Mechanism of } \\
\text { inhibition }\end{array}$ & Supplier & $\begin{array}{l}\text { Catalogue } \\
\text { number }\end{array}$ & $\begin{array}{l}\text { Stock } \\
\text { solvent }\end{array}$ \\
\hline Anisomycin & A-site (60S subunit) & $\begin{array}{l}\text { Peptide bond } \\
\text { formation }\end{array}$ & Sigma & A9789 & DMSO \\
\hline BAPTA & - & $\mathrm{Ca}^{2+}$ chelation & Abcam & $a b 120449$ & - \\
\hline Blasticidin S & $\begin{array}{l}\text { P-site }(60 S / 50 S \\
\text { subunits) }\end{array}$ & $\begin{array}{c}\text { Peptide bond } \\
\text { formation, termination }\end{array}$ & Sigma & 15205 & DMSO \\
\hline Cryptopleurine & $\begin{array}{l}\text { mRNA tunnel (40S } \\
\text { subunit) }\end{array}$ & Translocation & $\mathrm{NIH} / \mathrm{NCl}$ & NSC 19912 & DMSO \\
\hline Cycloheximide & E-site ( $60 \mathrm{~S}$ subunit) & Translocation & Sigma & 46401 & DMSO \\
\hline Deoxynivalenol & A-site (60S subunit) & $\begin{array}{l}\text { Peptide bond } \\
\text { formation }\end{array}$ & Sigma & D0156 & DMSO \\
\hline Edeine A1 & $\begin{array}{l}\text { mRNA tunnel (40S/30S } \\
\text { subunits) }\end{array}$ & Initiation & $\begin{array}{l}\text { lan Brierley } \\
\text { (Cambridge) }\end{array}$ & - & water \\
\hline Fusidic acid & Elongation factors & GTPase & Sigma & F0881 & water \\
\hline G418 & $\begin{array}{l}\text { Decoding centre } \\
\text { (40S/30S subunits) }\end{array}$ & $\begin{array}{l}\text { Translocation, } \\
\text { aminoacyl-tRNA } \\
\text { selection }\end{array}$ & Sigma & A1720 & water \\
\hline
\end{tabular}




\begin{tabular}{|c|c|c|c|c|c|}
\hline Chemical & Target & $\begin{array}{l}\text { Mechanism of } \\
\text { inhibition }\end{array}$ & Supplier & $\begin{array}{l}\text { Catalogue } \\
\text { number }\end{array}$ & $\begin{array}{l}\text { Stock } \\
\text { solvent }\end{array}$ \\
\hline $\begin{array}{c}\text { Homo- } \\
\text { harringtonine }\end{array}$ & A-site (60S subunit) & $\begin{array}{l}\text { Peptide bond } \\
\text { formation }\end{array}$ & Sigma & SML1091 & DMSO \\
\hline Hygromycin B & $\begin{array}{l}\text { Decoding centre } \\
\text { (40S/30S subunits) }\end{array}$ & $\begin{array}{l}\text { Translocation, } \\
\text { aminoacyl-tRNA } \\
\text { selection }\end{array}$ & Sigma & H9773 & DMSO \\
\hline Kanamycin & A-site ( $30 \mathrm{~S}$ subunit) & $\begin{array}{l}\text { Translocation, } \\
\text { aminoacyl-tRNA } \\
\text { selection }\end{array}$ & Fisher & BP906-5 & water \\
\hline Lactimidomycin & E-site (60S subunit) & Translocation & Merck Millipore & 506291 & DMSO \\
\hline Lanthanum & - & $\mathrm{Ca}^{2+}$ channel blocker & Sigma & 262072 & - \\
\hline Lycorine & A-site (60S subunit) & $\begin{array}{l}\text { Peptide bond } \\
\text { formation }\end{array}$ & Sigma & L5139 & DMSO \\
\hline Nagilactone C & A-site (60S subunit) & $\begin{array}{l}\text { Peptide bond } \\
\text { formation }\end{array}$ & $\mathrm{NIH} / \mathrm{NCl}$ & NSC 211500 & DMSO \\
\hline Narciclasine & A-site (60S subunit) & $\begin{array}{l}\text { Peptide bond } \\
\text { formation }\end{array}$ & $\mathrm{NIH} / \mathrm{NCl}$ & NSC 266535 & DMSO \\
\hline Phyllanthoside & E-site (60S subunit) & Translocation & $\mathrm{NIH} / \mathrm{NCl}$ & NSC 328426 & DMSO \\
\hline Puromycin & $\begin{array}{l}\text { A-site }(60 \mathrm{~S} / 50 \mathrm{~S} \\
\text { subunits) }\end{array}$ & Triggers termination & Sigma & P8833 & DMSO \\
\hline SBI-0640756 & elF4G & Initiation & Sigma & SML1645 & DMSO \\
\hline Silvestrol & elF4A & Initiation & $\mathrm{NIH} / \mathrm{NCl}$ & NSC 783538 & DMSO \\
\hline Verrucarin A & A-site (60S subunit) & $\begin{array}{l}\text { Peptide bond } \\
\text { formation }\end{array}$ & Sigma & V4877 & DMSO \\
\hline
\end{tabular}

\section{Generation of transgenic lines}

All vectors were constructed using Ligation-Independent Cloning, as described by Li \& Evans (1997), using a 30-second digestion with Exolll, and were transformed into $A$. thaliana using the floral dip method (Clough \& Bent, 1998). Primers used for cloning are given in Table 2.

CHX-resistant CYHr1 line: the RPL36aA gene was amplified from Col-0 genomic DNA with primers $12878+12879$. Mutated fragments were generated with primers $12880+12881,12882+12883$ and $12884+12885$ and were joined by overlap PCR to produce the gene RPL36aA $\triangle P 56 Q$. The binary vector PW1211 (Philip A. Wigge, unpublished) was linearised with Eco53kl and HindIII, and both $R P L 36 a A^{P 56 Q}$ and $P W 1211$ were recombined to produce $p C Y H r 1$

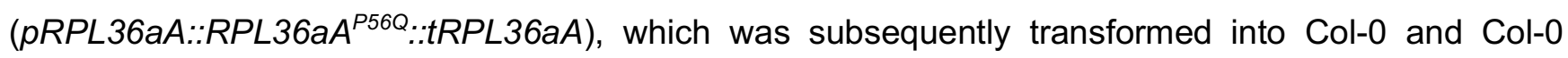
pCaMV35S::APOAEQUORIN. The mutated RPL36aA gene was expressed under its native promoter 
and terminator sequences. Two independent transgenic lines were used for experiments, named CYHr1-a and CYHr1-b.

CAMTA tagged lines for ChIP-seq: the CAMTA1, CAMTA2 and CAMTA3 genes were amplified in two parts from Col-0 genomic DNA with primers $10972+11015$ and 11014+10975, 10973+11017 and 11016+10976, and 10974+11019 and 11018+10977, respectively. PW1211 was linearised with Eco53kl and $E c 0 R V$ and recombined with both inserts to produce the plasmids $p C A M T A 1:: C A M T A 1:: F L A G \times 3$, pCAMTA2::CAMTA2::FLAG $\times 3$ and pCAMTA3::CAMTA3::FLAG $\times 3$, which were subsequently transformed into the camta123 triple mutant (Kim et al., 2013). All FLAG-tagged CAMTAs were expressed under their native promoter and terminator sequences.

CBF2 tagged line for ChIP-seq: the CBF2 terminator was amplified from Col-0 genomic DNA with primers $17400+17401$ and recombined with the vector pUBQ10-CFLAG (David GuillaumeSchoepfer \& Philip A. Wigge, unpublished), linearised with Stul and Afel, to produce the plasmid p3FLAG-tCBF2. The CBF2 gene was amplified with primers $17402+17403$ and recombined with p3FLAG-tCBF2, linearised with Pmel and BamHI, to generate the plasmid pCBF2::CBF2::FLAGx3::tCBF2, which was subsequently transformed into Col-0. FLAG-tagged CBF2 was expressed under its native promoter and terminator sequences.

Cold-inducible luciferase reporter lines: the $L U C$ coding sequence was amplified from $p B G W L 7$ (Karimi et al., 2005) with primers $13786+13787$, and the CBF2 and UBQ10 promoters and terminators were amplified from Col-0 genomic DNA with primers 13778+13779, 13784+13785, 13782+13783 and $13788+13789$, respectively. Fragments were re-amplified with primers $13999+13794$ or $13999+13796$ (LUC), 13795+13849 (tCBF2), 13797+13850 (tUBQ10), 13848+14000 or 13848+14001 (pCBF2) and $13749+14002$ or $13749+14003$ ( $p U B Q 10$ ), to produce overlapping ends, and the LUC coding sequence was joined to terminator regions by overlap PCR. PW1211 was linearised with Eco53kl and HindIII and recombined with the overlapped amplicons. The resultant vectors were linearised with Eco53kl and BamHI and recombined with promoter regions to produce the plasmids $p C B F 2:: L U C:: t C B F 2$, pCBF2::LUC::tUBQ10, pUBQ10::LUC::tUBQ10 and $p U B Q 10:: L U C:: t C B F 2$, which were transformed into Col-0.

Localised aequorin reporter lines: the coding sequences of VENUS and APOAEQUORIN were amplified from P2R-P3a_4glyVenusYFP-3AT (Yrjö Helariutta, unpublished) and pNEWAEQ (Alex Webb, unpublished) vectors using primers $12410+12411$ and $12412+12413$, respectively, and were joined by overlap PCR. The VENUS::APOAEQUORIN amplicon was re-amplified with primers $13842+12439$ and $13843+12439$ to introduce the SV40 nuclear localisation sequence or the human PK1 a nuclear export sequence, respectively (Mehlmer et al., 2012). These fragments were recombined with the vector $p U B Q 10-3 A T$ (David Guillaume-Schöpfer \& Philip A. Wigge, unpublished), linearised with BamHI and HindIII, to produce the plasmids pUBQ10::NLS SV40::VENUS::APOAEQUORIN and

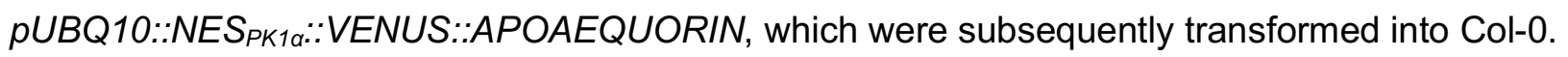


Plasmid for in vitro transcription and translation: the coding sequence of $L U C$ was amplified from pBGWL7 with primers 17404+17405 and recombined with the vector pTNT (L5610, Promega), linearised with Xhol and EcoRI. The resultant plasmid was linearised with Afel and BstZ17I and recombined with primers $17406+17407$, annealed to produce the FLAG tag, to generate the plasmid pTNT-LUC-FLAG×3.

\section{Gene expression analyses}

For expression analyses by quantitative PCR, total RNA was isolated from $A$. thaliana seedlings using phenol-chloroform extraction, as described by Box et al. (2011). Genomic DNA was eliminated by DNase I treatment using the TURBO DNA-free kit (AM1907, Invitrogen) and purified RNA was reversetranscribed using the Transcriptor First-Strand cDNA Synthesis Kit (04379012001, Roche), according to manufacturer instructions. Quantitative real-time PCR was carried out using a LightCycler 480 (Roche) with DNA SYBR Green I Master mix (04707516001, Roche). The following primers were used for quantitative PCR, with sequences listed in Table 2: 10964+10965 (CBF2/AT4G25470), 5343+5344 (PP2A/AT1G13320), 5297+5298 (UBC21/AT5G25760), 10953+10954 (COR15a/AT2G42540) and $13615+13616$ ( $L U C)$. The expression of CBF2, COR15a and LUC was normalised to the expression of both $P P 2 A$ and $U B C 21$. Because of the similarity in sequence between CBF1, CBF2 and CBF3 genes, the 'CBF2' primers used give an indication of total CBF expression. Crossing point (Cp) values were calculated using the 'Second Derivative Maximum Method' in the LightCycler software, and relative gene expression was subsequently calculated using the following formula:

$$
\text { Relative gene expression }=\frac{2^{-C p_{A}}}{\sqrt{\left(2^{-C_{F_{B}}}\right) \times\left(2^{-C_{F_{C}}}\right)}}
$$

where $A$ is the gene of interest and $B$ and $C$ are control genes used for normalisation.

For transcriptomic analyses by RNA-seq, total RNA was extracted and DNase-treated using MagMAX-96 Total RNA Isolation Kit (AM1830, Thermo Fisher Scientific). RNA was quantified using the Qubit fluorometer (Thermo Fisher Scientific) and RNA profiles were analysed using a TapeStation 2200 (Agilent) with RNA ScreenTapes (5067-5576, Agilent). Libraries for sequencing were prepared from 500 ng RNA using the QuantSeq 3' mRNA-Seq Library Prep Kit (Lexogen), according to manufacturer instructions. DNA libraries were quantified using a Qubit fluorometer, and library profiles were analysed using a TapeStation 2200 with High Sensitivity D1000 ScreenTapes (5067-5584, Agilent). Libraries were sequenced on a NextSeq-500 (Illumina; paired-end 75bp reads), according to Illumina guidelines.

Table 2: Primers used in this study

\begin{tabular}{|l|l|l|}
\hline Primer & Sequence (5'-3') & Purpose \\
\hline 12878 & AAGATGAGGAACAAAGAAAGAGAGTG & \\
\hline
\end{tabular}


bioRxiv preprint doi: $h$ ttps://doi.org/10.1101/2020.12.07.414789; this version posted December 7, 2020. The copyright holder for this preprint (which was not certified by peer review) is the author/funder, who has granted bioRxiv a license to display the preprint in perpetuity. It is made available under aCC-BY-NC-ND 4.0 International license.

\begin{tabular}{|c|c|c|}
\hline Primer & Sequence (5'-3') & Purpose \\
\hline 12879 & TTCTCAAAGCTTTGACATGTAAAGA & \multirow{7}{*}{ Cloning CYHr1 line } \\
\hline 12880 & GACCATGATTACGAATTCGAGCTCAAGATGAGGAACAAAGAAAGAGAGTG & \\
\hline 12881 & CTGACCACCATAACCAGACTGCTTTCGATCGTATCGACGCTTTCCTTGAGCAGC & \\
\hline 12882 & CAGTCTGGTTATGGTGGTCAGACTAAGCAAGTCTTCCACAAAAAGGTAACATTG & \\
\hline 12883 & СТTАССТTТСТTАТСТССТССGАТCTCGAAATGCTTGCAC & \\
\hline 12884 & TCGGAGGAGATAAGAAAGGTAAGGGAACATCTCTGTTTTAAGTTG & \\
\hline 12885 & ACGACGGCCAGTGCCAAGCTTTTCTCAAAGCTTTGACATGTAAAGA & \\
\hline 10972 & GACCATGATTACGAATTCGAGGTATCTTCTTTCTTCTTTTAAACGTAGTTT & \multirow{12}{*}{$\begin{array}{l}\text { Cloning FLAG- } \\
\text { tagged CAMTA } \\
\text { lines }\end{array}$} \\
\hline 10973 & GACCATGATTACGAATTCGAGGGGAAACAAGAAGGAAATAAAAA & \\
\hline 10974 & GACCATGATTACGAATTCGAGTGACCAGAAGAAAGAAAAAGAGA & \\
\hline 10975 & TCGTCGTCCTTATAATCGGATATAGGAGAAATAGACATCATCAATGTG & \\
\hline 10976 & TCGTCGTCCTTATAATCGGATATTTCAAATGCAAGAGACATGAAAG & \\
\hline 10977 & TCGTCGTCCTTATAATCGGATATACTGGTCCACAAAGATGAGGA & \\
\hline 11014 & GCAGGGGATAGTCAACAAGCAAG & \\
\hline 11015 & CTTGCTTGTTGACTATCCCСTGC & \\
\hline 11016 & CCCAAATGGACTCAGACAGACTC & \\
\hline 11017 & GAGTCTGTCTGAGTCCATTTGGG & \\
\hline 11018 & ATGTTGGACAAATACTCTCAGAAGCAC & \\
\hline 11019 & GTGCTTCTGAGAGTATTTGTCCAACAT & \\
\hline 17400 & GACGATGACAAGTGAGAGCTTCAGGAATTCGATTTTTATTTCCATTTTTGGTATTAT & \multirow{3}{*}{$\begin{array}{l}\text { Cloning FLAG- } \\
\text { tagged CBF2 line }\end{array}$} \\
\hline $\begin{array}{l}17401 \\
17402\end{array}$ & $\begin{array}{l}\text { GCAATTAAAGTAGGCCCACACAGAGCTACGTAAGAACTTGCGATGATGGATTTTTG } \\
\text { CCGCCAATATATCCTGTCAAACACTGATAGTTTAGAAATATGGGTCCCACAAGAGA }\end{array}$ & \\
\hline 17403 & СTTACTAACACTTGCAAGCTTCTCTCTGGATCCATAGCTCCATAAGGACACGTCAT & \\
\hline 13749 & GACCATGATTACGAATTCGAGATTTATGGATACACAGTCTAGCTCAACAG & \multirow{12}{*}{$\begin{array}{l}\text { Cloning cold- } \\
\text { inducible luciferase } \\
\text { lines }\end{array}$} \\
\hline 13778 & AGAAATATGGGTCCCACAAG & \\
\hline 13779 & TGATCAGAAGAGTACTCTGTTTCAAG & \\
\hline 13782 & AATTCGATTTTTATTTCCATTTTTGG & \\
\hline 13783 & TACGTAAGAACTTGCGATGATG & \\
\hline $\begin{array}{r}13784 \\
13785\end{array}$ & $\begin{array}{l}\text { ATTTATGGATACACAGTCTAGCTCAA } \\
\text { CTGTTAATCAGAAAAACTCAGATTAATCG }\end{array}$ & \\
\hline 13786 & ATGGAAGACGCCAAAAACATAAAG & \\
\hline 13787 & TTACAATTTGGACTTTCCGC & \\
\hline 13788 & ATCTCGTCTCTGTTATGCTTAAGAAG & \\
\hline 13789 & GTGTCATATAGGTCTCATAACCTITATAAAT & \\
\hline 13794 & TCCAAATTGTAAAATTCGATTTTTATTT & \\
\hline 13795 & AAATAAAAATCGAATTTTACAATTTGGA & \\
\hline
\end{tabular}


bioRxiv preprint doi: https://doi.org/10.1101/2020.12.07.414789; this version posted December 7. 2020. The copvriaht holder for this preprint (which was not certified by peer review) is the author/funder, who has granted bioRxiv a license to display the preprint in perpetuity. It is made available under aCC-BY-NC-ND 4.0 International license.

\begin{tabular}{|c|c|c|}
\hline Primer & Sequence (5'-3') & Purpose \\
\hline 13796 & GTCCAAATTGTAAATCTCGTCTCT & \\
\hline 13797 & AGAGACGAGATTTACAATTTGGAC & \\
\hline 13848 & CAGCTATGACCATGATTACGAATTCGAGAGAAATATGGGTCCCACAAG & \\
\hline 13849 & ACGACGGCCAGTGCCAAGCTTACGTAAGAACTTGCGATGATG & \\
\hline 13850 & ACGACGGCCAGTGCCAAGCTGTGTCATATAGGTCTCATAACCTTTATAAAT & \\
\hline 13999 & CAGCTATGACCATGATTACGAATTCGAGCTCGGATCCATGGAAGACGCCAAAAAC & \\
\hline 14000 & GAAAAGGCAGAAAATGAGTTCATGGATCTGATCAGAAGAGTACTCTGTTTCAAG & \\
\hline 14001 & CTITATGTTTITGGCGTCTTCCATGGATCTGATCAGAAGAGTACTCTGTTTCAAG & \\
\hline 14002 & GAAAAGGCAGAAAATGAGTTCATGGATCCTGTTAATCAGAAAAACTCAGATTAATC & \\
\hline 14003 & CTITATGTTTTTGGCGTCTTCCATGGATCCTGTTAATCAGAAAAACTCAGATTAATC & \\
\hline 12410 & GGTTTTCAGTATAATGTTACATGCGTACACGCGTATGGTGAGCAAGGGCGAGGA & \multirow{6}{*}{$\begin{array}{l}\text { Cloning localised } \\
\text { aequorin reporter } \\
\text { lines }\end{array}$} \\
\hline 12411 & TGAGTATTGTTCGCTGGTCATAATAGCTCCTCCAGAAGCTCCCAAAGCTCCCTTGT & \\
\hline 12412 & GCATGGACGAGCTGTACAAGGGAGCTTTGGGAGCTTCTGGAGGAGCTATTATGAC & \\
\hline 12413 & GAAATAGCTCCATTTTGAGCTTTGTCAATGATA & \\
\hline 12439 & ACGAAAGCTGGGAGGCCTGAAGCTTCAGGGGACAGCTCCACCGTA & \\
\hline 13842 & CGATTAATCTGAGTTTTTCTGATTAACAGGGATCATGTTGCAACCTAAGAAGAAGA & \\
\hline 17404 & AAGCTACTTGTTCTTTTTGCACTCGAATGGAAGACGCCAAAAACATAAAG & \multirow{3}{*}{$\begin{array}{l}\text { Cloning pTNT- } \\
\text { LUC-FLAGx3 }\end{array}$} \\
\hline $\begin{array}{r}17405 \\
17406\end{array}$ & $\begin{array}{l}\text { CGACTCTAGAGGTACCACGCGTGTATACAGCGCTAGCCTTACTAACACTAGCCA } \\
\text { GCTAGTGTTAGTAAGGCTGATTATAAAGATGACGATGACAAGGATTATAAAGATG }\end{array}$ & \\
\hline 17407 & CTAGAGGTACCACGCGTGAATTTCACTTGTCATCGTCATCTTTATAATCCTTGTCA & \\
\hline 5297 & TCCTCTTAACTGCGACTCAGG & \multirow{10}{*}{ Quantitative PCR } \\
\hline 5298 & GCGAGGCGTGTATACATTTG & \\
\hline 5343 & GCGGTTGTGGAGAACATGATACG & \\
\hline 5344 & GAACCAAACACAATTCGTTGCTG & \\
\hline 10953 & CAGTGAAACCGCAGATACATTGG & \\
\hline 10954 & TCCTCCACATACGCCGCAG & \\
\hline 10964 & TGGATGAAGAGGCGATGTTGGG & \\
\hline 10965 & GGCGACGGTAAAAGCATCCCT & \\
\hline 13615 & GGATTCTAAAACGGATTACCAGGG & \\
\hline 13616 & CCACACCCTTAGGTAACCCAGTAGAT & \\
\hline
\end{tabular}

\section{Chromatin immunoprecipitation}

The seedling were grown for 10 days and treated as indicated. $3 \mathrm{~g}$ plant material for each treatment was fixed under vacuum for $20 \mathrm{~min}$ in 1 XPBS $\left(10 \mathrm{mM} \mathrm{PO}_{4}{ }^{3-}, 137 \mathrm{mM} \mathrm{NaCl}\right.$, and 2.7 $\mathrm{mM} \mathrm{KCl}$ ) containing 1\% Formaldehyde (F8775 SIGMA). The reaction was quenched by adding glycine to a final concentration of $62 \mathrm{mM}$. Chromatin immunoprecipitation (ChIP) was performed 
as described (Jaeger et al), with the exception that $100 \mu$ of ANTI-FLAG® M2 Affinity Gel ( A2220 Sigma) were used for Immunoprecipitation seedlings. Sequencing libraries were prepared using TruSeq ChIP Sample Preparation Kit (Illumina IP-202-1024) and prepared according to manufacturer instructions. DNA libraries were quantified using a Qubit fluorometer, and library profiles were analysed using a TapeStation 2200 with High Sensitivity D1000 ScreenTapes (5067-5584, Agilent). Libraries were sequenced on a NextSeq-500 (Illumina; single end, $75 \mathrm{bp}$ reads), according to Illumina guidelines.

\section{Bioinformatic methods}

RNA-seq samples were analysed with a commercial pipeline (QuantSeq FWD; Bluebee).

From the processed count files, CPM values (counts per million reads mapped) were calculated for each annotated gene and used as the abundance measure.

For ChIP-seq reads, adaptor contamination and low-quality trailing sequences were removed using Trimmomatic (Bolger et al., 2014). Trimmed reads were mapped to the TAIR10 transcriptome using Bowtie2 (Langmead \& Salzberg, 2012). Any read that mapped to more than one genomic location was discarded and optical duplicates were removed using Picard (http://github.com/broadinstitute/picard). Genomic binding profiles were quantified in RPKM (reads per kilobase per million mapped reads) using a bin-size of $10 \mathrm{bp}$. Peaks were identified with Model-based Analysis of ChIP-seq (MACS2) (Zhang et al., 2008) with argument "--keep-dup 1 -p 0.1", and peaks were filtered for fold-change $>4$ (Fig. 3) or $>6$ (Supp. Fig. 3E). Any gene containing a peak summit within $3 \mathrm{~kb}$ of its start codon was classified as a bound target. For ChIP-seq pile-ups, RPKM profiles were extracted for each peak around the MACS2-reported summit position and per-position averages and standard deviations were calculated across target peaks. The ChIP-seq data was visualised with the Integrated Genome Viewer (IGV), and for IGV snapshots the same y-axis scales were used for all tracks (Fig. 3C and Supp. Fig. 3D).

Gene lists for Venn diagrams, top 1000 high-confidence (based on FC) ChIP genes

Raw and processed RNA-seq and ChIP-seq data are available online (NCBI Geo Ominibus accession GSEXXXXXX and GSEXXXXXX). Code for reproducing the analysis is available at https://www.github.com/shouldsee/camta-figures.

Analyses of promoter motif enrichment were carried out using Homer2 (Heinz et al., 2010) with promoter sequences retrieved from TAIR (TAIR10 Loci Upstream Seq -1000bp; https://www.arabidopsis.org/tools/bulk/sequences/).

\section{In vitro transcription and translation}


pTNT-LUC-FLAG $\times 3$, described above, was linearised with BamHI and uncapped transcripts were synthesised in vitro for 6 hours at $37^{\circ} \mathrm{C}$ using bacteriophage T7 RNA polymerase (EP0112, Thermo Fisher Scientific) in a $50 \mu \mathrm{L}$ reaction supplemented with $20 \mathrm{U}$ SUPERase-In RNase inhibitor (AM2694, Thermo Fisher Scientific), 4 mM NTPs and 5 mM DTT. DNA was removed in a 30-minute digestion with DNAse I at $37^{\circ} \mathrm{C}$ and RNA was subsequently purified using 1:1 phenol-chloroform ( $\left.\mathrm{pH} 4.3\right)$ and ethanolprecipitated.

In vitro translation was performed for one hour at the temperatures indicated $\left(0^{\circ} \mathrm{C}\right.$ to $\left.35^{\circ} \mathrm{C}\right)$, using wheat germ extracts (L4380, Promega) in $40 \mu \mathrm{L}$ reactions supplemented with all amino acids, $70 \mathrm{mM}$ potassium acetate, $0.4 \mathrm{ug}$ denatured RNA, $16 \mathrm{U}$ SUPERase-In RNase inhibitor (AM2694, Thermo Fisher Scientific) and $1 \times$ complete EDTA-free protease inhibitors (11873580001, Roche). Reactions were stopped by adding $\mathrm{CHX}$ and EDTA to final concentrations of $100 \mu \mathrm{M}$ and $300 \mu \mathrm{M}$, respectively, and placing the tubes on ice. To measure the activity of recombinant luciferase, sodium-D-luciferin and ATP were added to the reactions to final concentrations of $100 \mu \mathrm{M}$ and $50 \mu \mathrm{M}$, respectively, and luminescence was quantified at room temperature using a TriStar LB-942 plate reader (Berthold). To measure the protein yield, reactions were mixed with SDS loading buffer $(60 \mathrm{mM}$ Tris- $\mathrm{HCl} \mathrm{pH} 6.8,10 \%$ $\mathrm{v} / \mathrm{v}$ glycerine, $2 \% \mathrm{w} / \mathrm{v}$ SDS, $100 \mathrm{mM}$ DTT, 0.015\% w/v bromophenol blue; final concentrations) and FLAG-labelled proteins were analysed as described below.

\section{Western blotting}

Frozen seedlings were pulverised in $2 \mathrm{~mL}$ tubes containing a single tungsten carbide bead (69997, Qiagen) using the Tissue Lyser II (Qiagen). Proteins were extracted using the urea-SDS method outlined by Clontech (2009), with $150 \mu \mathrm{L}$ cracking buffer per 10 to 20 pulverised seedlings. Protein extracts were separated by SDS-polyacrylamide gel electrophoresis, transferred onto PVDF membranes and probed with horseradish peroxidase (HRP)-conjugated anti-FLAG (A8592, Sigma; 1:3000), anti-puromycin (MABE343, Sigma; 1:1000), anti-actin (A0480, Sigma; 1:3000) or anti-RPS14 (AS12-2111, Agrisera; 1:3000) primary antibodies and DyLight 800-conjugated anti-mouse IgG (AS122426, Agrisera) or DyLight 650-conjugated anti-rabbit IgG (AS12-2327, Agrisera) secondary antibodies. Washes were carried out in $1 \times$ TBST buffer $(20 \mathrm{mM}$ Tris- $\mathrm{HCl}, 150 \mathrm{mM} \mathrm{NaCl}, 0.1 \%$ v/v Tween-20) and blocking and incubations were carried out with $5 \% \mathrm{w} / \mathrm{v}$ BSA or skimmed milk in $1 \times$ TBST buffer. Chemiluminescence was quantified using Pierce ECL Western Blotting Substrate (32106, Thermo Scientific) over a period of five minutes, and $600 \mathrm{~nm}, 700 \mathrm{~nm}$ or $800 \mathrm{~nm}$ fluorescence emission detection was measured for 30 seconds, using a dual-mode camera (Odyssey Fc, Li-Cor) coupled with an imaging suite (Image Studio v.2.1.10, Li-Cor). The intensity of protein bands was measured using ImageJ (NIH).

For SUnSET assays (Schmidt et al., 2009), the level of in vivo translation was determined by measuring the amount of puromycin-labelled proteins, normalised to actin levels, and is given as a percentage of maximal puromycin incorporation. For time-course experiments, puromycin incorporation 
in $\mathrm{CHX}$ - and cold-treated seedlings were additionally normalised to that in mock controls for each time point.

\section{Fluorescence microscopy}

Confocal images were obtained using a Leica SP8 laser-scanning confocal microscope with $20 \times / 0.75$ or $63 \times / 1.2$ objectives (Leica Microsystems, Wetzlar, Germany). The fluorescent protein Venus (modified yellow fluorescent protein, YFP) was excited using a white light laser at $514 \mathrm{~nm}$, with detection restricted to $520-550 \mathrm{~nm}$.

Samples for immunofluorescence microscopy were prepared as described by Pasternak et al. (2015), with the following modifications. Seven-days-old seedlings were fixed for two hours in $2 \%$ formaldehyde solution and, following tissue clearing with methanol, were digested for 8 minutes at $37^{\circ} \mathrm{C}$ in digestion solution (4 ng/ $\mathrm{LL}$ cellulase R-10 [C8001, Duchefa], $4 \mathrm{ng} / \mu \mathrm{L}$ macerozyme R-10 [M8002, Duchefa], $6 \mathrm{ng} / \mu \mathrm{L}$ pectinase [17389, Sigma-Aldrich], $2 \mathrm{ng} / \mu \mathrm{L}$ pectolyase Y-23 [P8004, Duchefa] in 1x PBST buffer [137 mM NaCl, $2.7 \mathrm{mM} \mathrm{KCl}, 8 \mathrm{mM} \mathrm{Na}_{2} \mathrm{HPO}_{4}, 1.5 \mathrm{mM} \mathrm{KH}_{2} \mathrm{PO}_{4}, 0.01 \%$ v/v Tween-20, pH 4.7]). Following membrane permeabilisation, seedlings were incubated with gentle mixing firstly in blocking solution (5\% BSA in 1× PBST buffer) for 2 hours at room temperature and then in 1:500 antibody solutions (anti-puromycin [MABE343, Sigma] primary antibody, and DyLight 650-conjugated anti-mouse IgG [AS12-2302, Agrisera] secondary antibody, both in blocking solution) overnight at $4^{\circ} \mathrm{C}$, with three washes with $1 \times$ PBST buffer after each antibody incubation. DyLight 650 was excited using a white laser at $633 \mathrm{~nm}$, with detection restricted to 668-678 nm. Images were analysed with ImageJ $(\mathrm{NIH})$.

For wide-field $\mathrm{Ca}^{2+}$ imaging analyses in $A$. thaliana root tip cells, an inverted fluorescence Nikon microscope (Ti-E) with a 20× N.A. 0.75 was used. Excitation light was produced by a fluorescent lamp (Prior Lumen 200 PRO, Prior Scientific) set to $20 \%$ with $440 \mathrm{~nm}(436 / 20 \mathrm{~nm}$ ) excitation for the Cameleon (YC3.6) sensor. Images were collected with a Hamamatsu Dual CCD camera (ORCA-D2). The FRET CFP/YFP optical block A11400-03 (emission 1, 483/32 nm for CFP; emission 2, 542/27 nm for FRET) was used with a dichroic 510-nm mirror (Hamamatsu) for simultaneous CFP and cpVenus acquisitions. Camera binning was set to $2 \times 2$ with exposure times of $200 \mathrm{~ms}$. Images where acquired every $5 \mathrm{~s}$. Filters and dichroic mirrors were purchased from Chroma Technology. NIS-ElementsTM (Nikon) was used as a platform to control the microscope, illuminator and camera. Images were analysed using FIJI.

\section{Measurements of intracellular free calcium}

For aequorin-based measurements, three seedlings grown in $1 / 2 \mathrm{MMG}$ medium for eight to twelve days were transferred to $500 \mu \mathrm{L}$ freshly-prepared $2 \mu \mathrm{M}$ coelenterazine solution (303-500, Nanolight Technology; in deionised water with $0.5 \% \mathrm{v} / \mathrm{v}$ methanol) in luminometer cuvettes (diameter $12 \mathrm{~mm}$, height $51 \mathrm{~mm}$; Sarstedt). Following reconstitution of aequorin in the dark at $20^{\circ} \mathrm{C}$ for at least 10 hours, 
the coelenterazine was replaced with $500 \mu \mathrm{L} 30 \mu \mathrm{M} \mathrm{CHX}, 30 \mu \mathrm{M}$ kanamycin or $0.1 \% \mathrm{v} / \mathrm{v}$ DMSO (mock control) in deionised water at $20^{\circ} \mathrm{C}$. The cuvette was immediately placed in a photon-counting luminometer ( $9899 \mathrm{~A}$ photomultiplier tube; cooled to $-20^{\circ} \mathrm{C}$ with a FACT50 housing [Electron Tubes]) and photon counts were measured every second. To estimate total aequorin in the samples, $1 \mathrm{~mL}$ of discharge solution ( $1 \mathrm{M} \mathrm{CaCl}_{2}, 10 \% \mathrm{v} / \mathrm{v}$ ethanol, final concentrations) was injected into the cuvette through a light-tight port in the luminometer using a $1 \mathrm{~mL}$ syringe and $75 \mathrm{~mm}$ needle. Measurements were continued until photon counts/sec had reached $<10 \%$ of the discharge peak. Nuclear and cytosolic free calcium levels were measured using $p U B Q 10:: N L S_{S V 40}:: V E N U S:: A P O A E Q U O R I N$ and

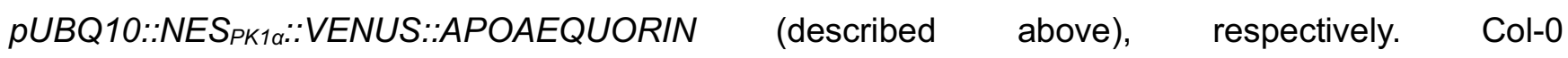
pCaMV35S::APOAEQUORIN and CYHr1 pCaMV35S::APOAEQUORIN were used for non-localised measurements of intracellular free calcium ions (cytosolic and nuclear). Calcium concentrations were estimated according to Fricker et al. (1999) using the following formula:

$\left[\mathrm{Ca}^{2+}\right]_{\mathrm{i}}(\mathrm{nM})=10^{\wedge}-(0.332588(-\log \mathrm{k})+5.5593) * 10^{9}$

where $\mathrm{k}=$ photon count $/$ total photon count over course of experiment.

For Cameleon-based measurements, seedlings grown on MS agar for seven days were gently transferred to dedicated chambers and overlaid with cotton wool soaked in imaging solution $(5 \mathrm{mM} \mathrm{KCl}$, $10 \mathrm{mM}$ MES, $10 \mathrm{mM} \mathrm{CaCl}_{2}$, adjusted to $\mathrm{pH} 5.8$ with Tris). The root was continuously perfused with imaging solution, whereas the shoot was not submerged. The treatment was carried out by adding $\mathrm{CHX}$ to the imaging solution at a final concentration of $30 \mu \mathrm{M}$ at the indicated time. Fluorescence intensity was determined over a region of interest (ROI), corresponding to the root tip meristematic zone (Behera et al., 2018). cpVenus and CFP emissions in the analysed ROI were used for the ratio (R) calculation (cpVenus/CFP), which was normalised to the initial ratio $\left(R_{0}\right)$ and plotted versus time $\left(\Delta R / R_{0}\right)$.

Background subtraction was performed independently for both channels before calculating the ratio.

Supplementary references:

Kim, Y., Park, S., Gilmour, S. J., \& Thomashow, M. F. (2013). Roles of CAMTA transcription factors and salicylic acid in configuring the low-temperature transcriptome and freezing tolerance of Arabidopsis. The Plant Journal, 75(3), 364-376. https://doi.org/10.1111/tpj.12205

Kidokoro, S., Yoneda, K., Takasaki, H., Takahashi, F., Shinozaki, K., \& Yamaguchi-Shinozaki, K. (2017). Different Cold-Signaling Pathways Function in the Responses to Rapid and Gradual Decreases in Temperature. The Plant Cell, 29(4), 760-774. https://doi.org/10.1105/TPC.16.00669

Nakamichi, N., Kita, M., Ito, S., Yamashino, T., \& Mizuno, T. (2005). PSEUDO-RESPONSE REGULATORS, PRR9, PRR7 and PRR5, Together play essential roles close to the circadian clock of Arabidopsis thaliana. Plant and Cell Physiology, 46(5), 686-698. https://doi.org/10.1093/pcp/pci086

Xu, X., Hotta, C. T., Dodd, A. N., Love, J., Sharrock, R., Young, W. L., Xie, Q., Johnson, C. H., \& Webb, A. A. R. (2007). Distinct light and clock modulation of cytosolic free Ca2+ oscillations and rhythmic CHLOROPHYLL A/B BINDING PROTEIN2 promoter activity in Arabidopsis. Plant Cell, 19(11), 3474-3490. https://doi.org/10.1105/tpc.106.046011 
Krebs, M., Held, K., Binder, A., Hashimoto, K., Den Herder, G., Parniske, M., Kudla, J., \& Schumacher, K. (2012). FRET-based genetically encoded sensors allow high-resolution live cell imaging of $\mathrm{Ca}$ 2+ dynamics. Plant Journal, 69(1), 181-192. https://doi.org/10.1111/j.1365-313X.2011.04780.x

Clough, S. J., \& Bent, A. F. (1998). Floral dip: A simplified method for Agrobacterium-mediated transformation of Arabidopsis thaliana. Plant Journal, 16(6), 735-743. https://doi.org/10.1046/j.1365-313X.1998.00343.x

Schmidt, E. K., Clavarino, G., Ceppi, M., \& Pierre, P. (2009). SUnSET, a nonradioactive method to monitor protein synthesis. Nature Methods, 6(4), 275-277. https://doi.org/10.1038/nmeth.1314

Li, C., \& Evans, R. M. (1997). Ligation independent cloning irrespective of restriction site compatibility. Nucleic Acids Research, 25(20), 4165-4166. http://www.ncbi.nlm.nih.gov/pubmed/9321675

Karimi, M., De Meyer, B., \& Hilson, P. (2005). Modular cloning in plant cells. Trends in Plant Science, 10(3), 103-105. https://doi.org/10.1016/j.tplants.2005.01.008

Mehlmer, N., Parvin, N., Hurst, C. H., Knight, M. R., Teige, M., \& Vothknecht, U. C. (2012). A toolset of aequorin expression vectors for in planta studies of subcellular calcium concentrations in Arabidopsis thaliana. Journal of Experimental Botany, 63(4), 1751-1761. https://doi.org/10.1093/jxb/err406

Box, M. S., Coustham, V., Dean, C., \& Mylne, J. S. (2011). Protocol: A simple phenol-based method for 96-well extraction of high quality RNA from Arabidopsis. Plant Methods, 7(1), 1-10. https://doi.org/10.1186/1746-4811-7-7

Clontech Laboratories (2009) Preparation of Yeast Protein Extracts. In: Yeast Protocols Handbook. Protocol No. PT3024-1. Mountain View, CA: Takara Bio. Ch.4.

Pasternak, T., Tietz, O., Rapp, K., Begheldo, M., Nitschke, R., Ruperti, B., \& Palme, K. (2015). Protocol: An improved and universal procedure for whole-mount immunolocalization in plants. Plant Methods, 11(1), 1-10. https://doi.org/10.1186/s13007-015-0094-2

Fricker, M. D., Plieth, C., Knight, H., Blancaflor, E., Knight, M. R., White, N. S. \& Gilroy, S. (1999) Fluorescence and Luminescence Techniques to Probe Ion Activities in Living Plant Cells. In: Mason, W.T., ed. (1999) Fluorescent and Luminescent Probes for Biological Activity. San Diego, USA: Academic Press.

Behera, S., Xu, Z., Luoni, L., Bonza, M. C., Doccula, F. G., De Michelis, M. I., Morris, R. J., Schwarzländer, M., \& Costa, A. (2018). Cellular Ca 2+ signals generate defined pH signatures in plants. Plant Cell, 30(11), 2704-2719. https://doi.org/10.1105/tpc.18.00655

Jaeger KE, Pullen N, Lamzin S, Morris RJ, Wigge PA (2013). Interlocking feedback loops govern the dynamic behavior of the floral transition in Arabidopsis.

Plant Cell. 2013 Mar;25(3):820-33. doi: 10.1105/tpc.113.109355. Epub 2013 Mar 29. 
Supplementary Figure 1: Ambient temperature has an inherent

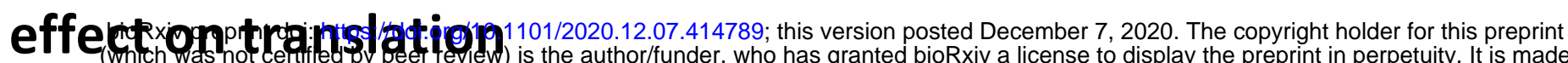
the author/funder, who has granted bioRxiv a license to display the preprint in perpetuity. It is made available under aCC-BY-NC-ND 4.0 International license.

A

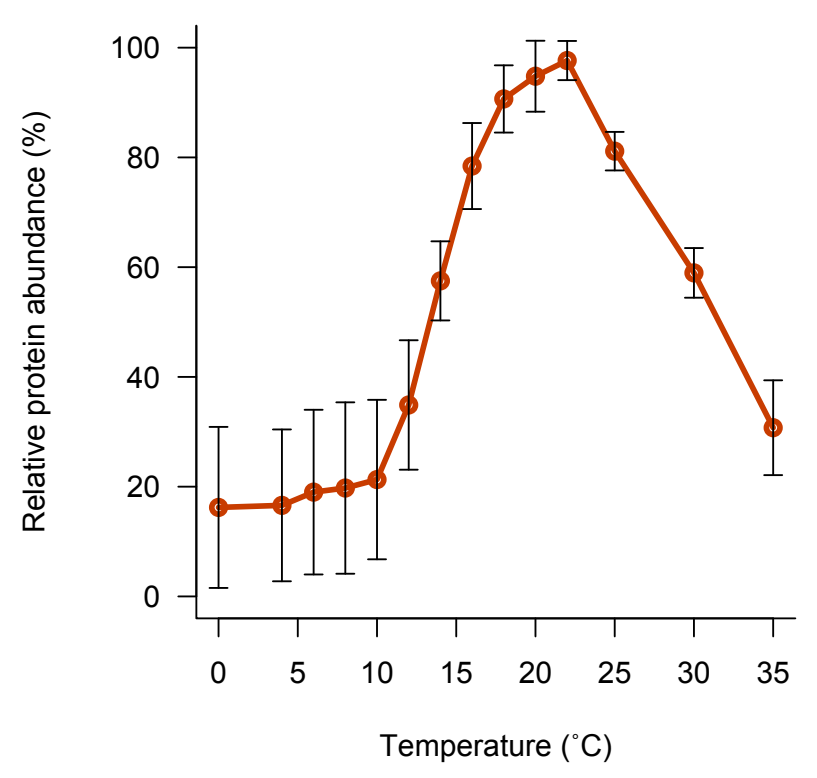

B

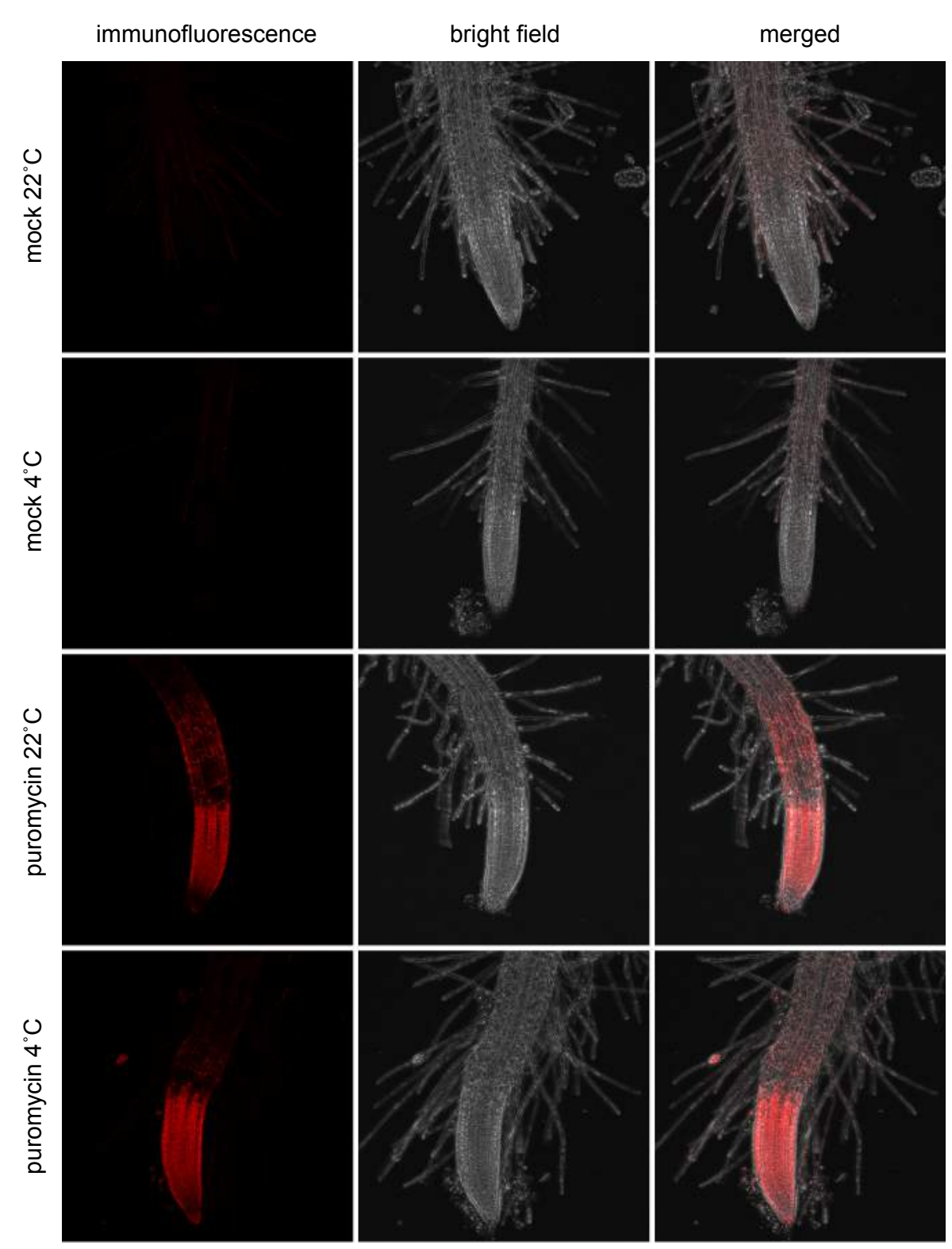




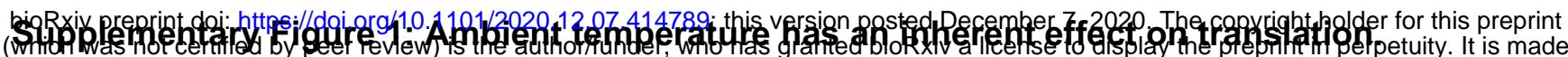
A: Low temperatures reduce protein synthesis in vitro. Protein yield of C-terminally FLAG-tagged luciferase synthesised in vitro using wheat germ extract for 1 hour at $0^{\circ} \mathrm{C}$ to $35^{\circ} \mathrm{C}$. FLAG-labelled protein levels were normalised to RPS14 levels and are given as a percentage of the maximum yield. All translation reactions contained equal amounts of mRNA. Error bars indicate the standard deviation for 4 replicate reactions. B: Low temperatures do not prevent the cellular uptake of puromycin. Arabidopsis thaliana Col-0 seedlings were grown in liquid culture in long days at $22^{\circ} \mathrm{C}$ for 7 days and, following a 2-hour pre-incubation at either $4^{\circ} \mathrm{C}$ or $22^{\circ} \mathrm{C}$, were treated with $150 \mu \mathrm{M}$ puromycin or $0.1 \%$ DMSO (mock) for 30 minutes at these respective temperatures and subsequently fixed with formaldehyde. Intracellular puromycin was detected by immunofluorescence microscopy for 7 biological replicates with the same laser settings and representative images are shown. 


\section{Supplementary Figure 2: CBF2 induction by $\mathrm{CHX}$ treatments}

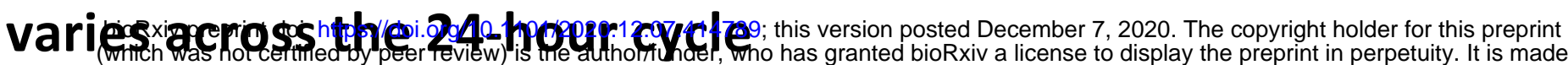
available under aCC-BY-NC-ND 4.0 International license.
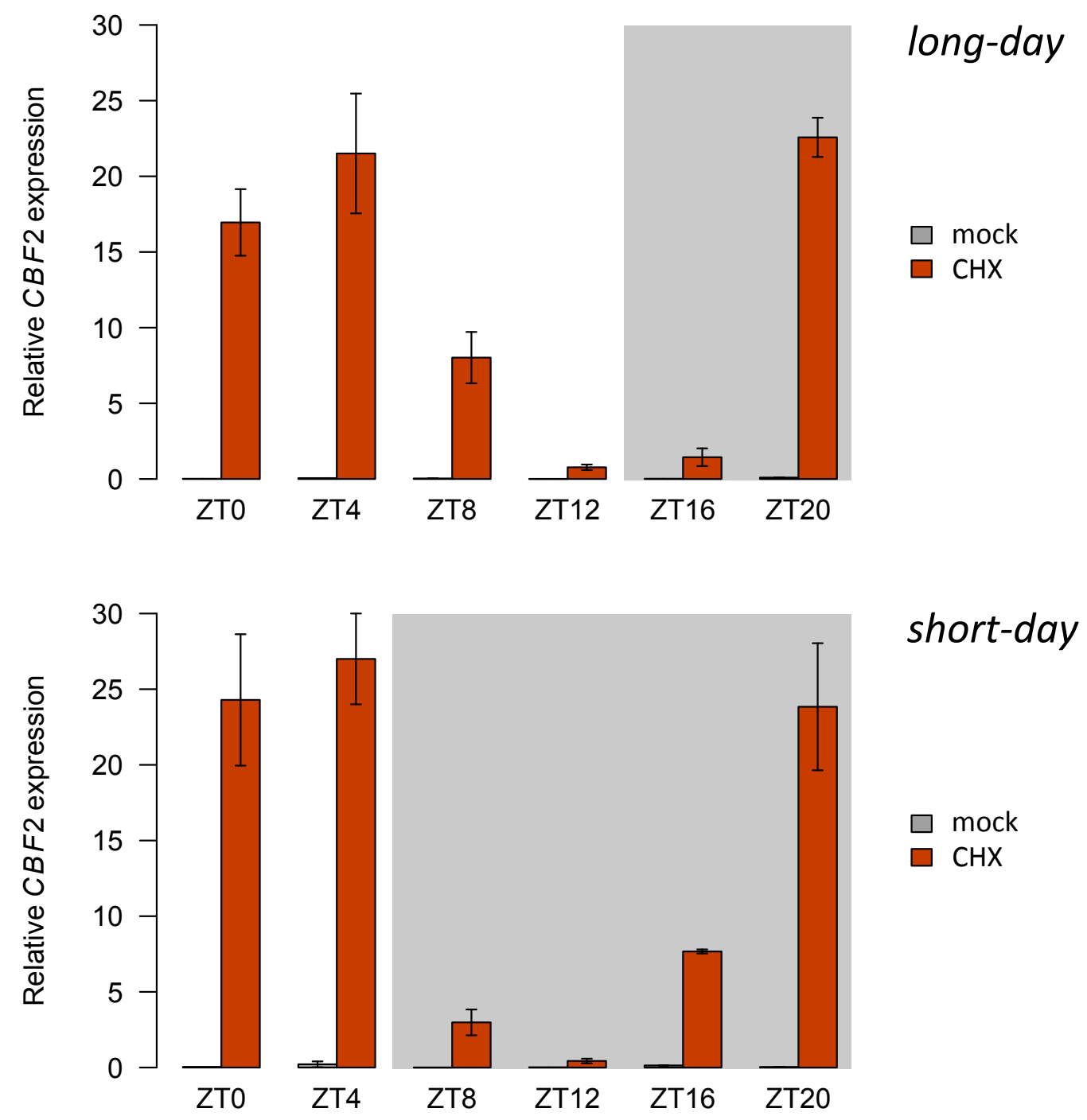

short-day

$\square$ mock

$\square \mathrm{CHX}$ 


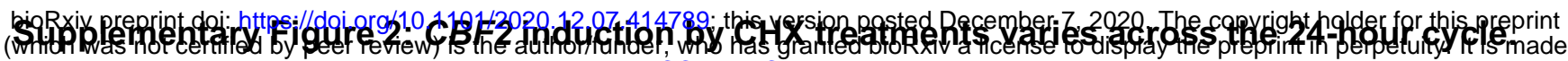
A. thaliana Col-0 seedlings were grown in liquid culture for 9 days at $22^{\circ} \mathrm{C}$ with a long-day (16-hour) or short-day (8-hour) photoperiod and harvested after 2-hour treatments at $22^{\circ} \mathrm{C}$ with $30 \mu \mathrm{M} \mathrm{CHX}$ or $0.1 \%$ DMSO (mock) at the indicated intervals. CBF2 expression was determined by quantitative PCR and normalised to transcript levels of PP2A and UBC21. Error bars represent standard deviation for 3 biological replicates, with 10-15 seedlings per replicate. Grey boxes represent treatments performed in the dark. 


\section{Supplementary Figure 3: ChIP-seq of FLAG-tagged lines}

bioRxiv preprint doi: https://doi.org/10.1101/2020.12.07.414789; this version posted December 7, 2020. The copyright holder for this preprint (which was not certified by peer review) is the author/funder, who has granted bioRxiv a license to display the preprint in perpetuity. It is made available under aCC-BY-NC-ND 4.0 International license.

A

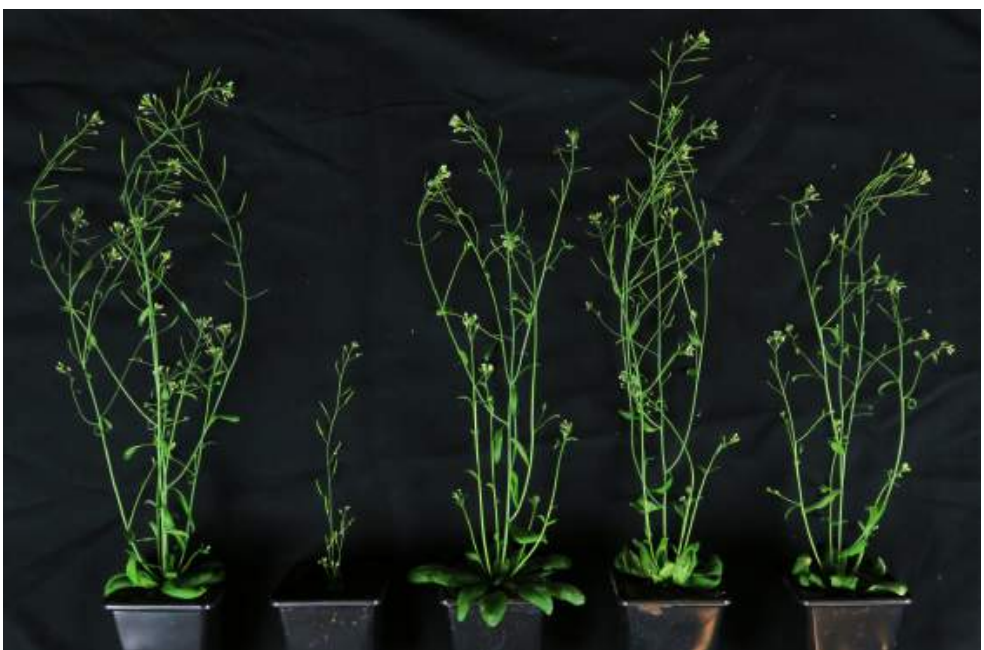

\section{5 weeks}

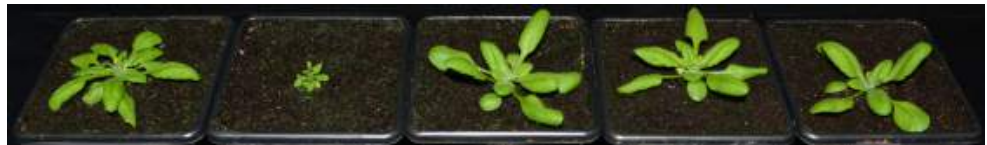

3 weeks

B

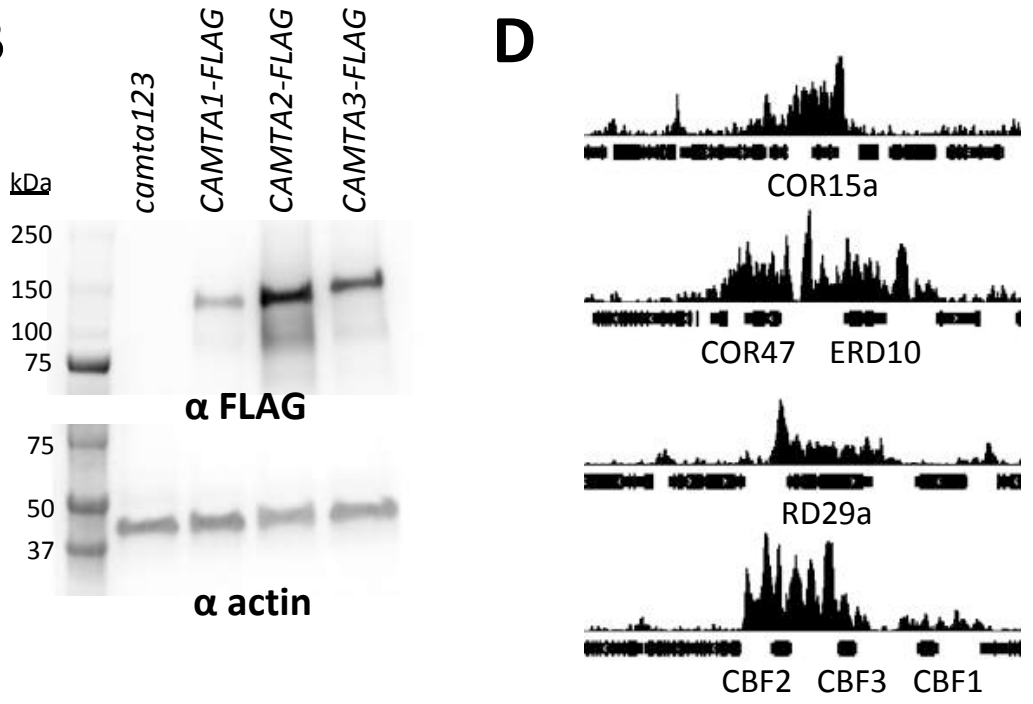

C

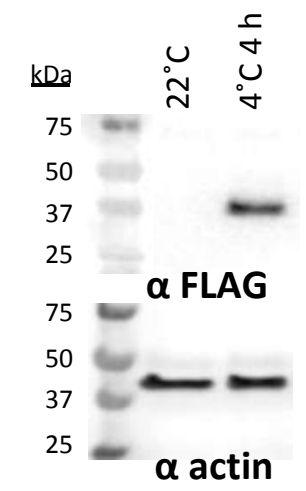

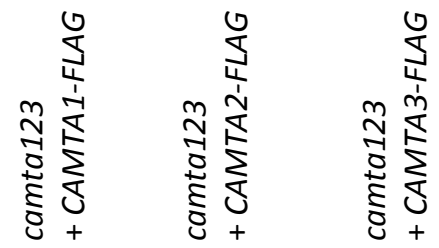

$\mathbf{E}$

(1)

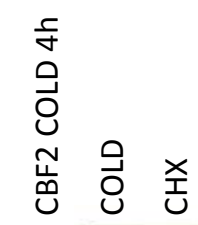




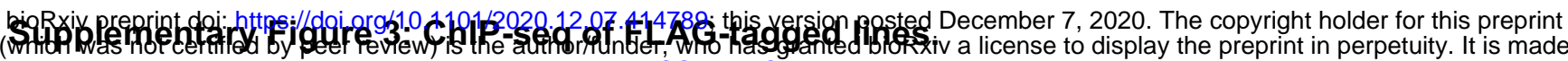

A: Complementation of the camta123 mutant with a C-terminal FLAG-tagged CAMTA1, 2 or 3 (pCAMTA1::CAMTA1::FLAG×3, pCAMTA2::CAMTA2::FLAG×3, or pCAMTA3::CAMTA3::FLAG× 3). Images of homozygous $A$. thaliana plants after 3 or 5 weeks of growth at $22^{\circ} \mathrm{C}$ in long days. $\mathrm{B}$ : Protein expression of FLAG-tagged CAMTA1, 2 and 3 , and of actin as a loading control, in homozygous complemented camta123 A. thaliana seedlings grown for 7 days in liquid medium at $22^{\circ} \mathrm{C}$ in long days. C: Protein expression of FLAG-tagged CBF2, and of actin as a loading control, in homozygous Col-0 seedlings grown for 7 days in liquid medium at $22^{\circ} \mathrm{C}$ in long days and either transferred to $4^{\circ} \mathrm{C}$ for 4 hours or maintained at $22^{\circ} \mathrm{C}$. D: Cold-associated binding of CBF2 at coldinducible genes COR15a (AT2G42540), COR47 (AT1G20440), ERD10 (AT1G20450), RD29a (AT5G52310), CBF2 (AT4G25470) and CBF3 (AT4G25480), 4 hours after transfer from $22^{\circ} \mathrm{C}$ to $4^{\circ} \mathrm{C}$. No binding is detected at control genes PP2A (AT1G13320), UBC21 (AT5G25760) and HSP70 (AT3G12580), which are not induced at low temperatures. E: Target genes of CAMTAs and CBF2 detected by ChIP-seq. Blue tick marks indicate genes at which a 6-fold increase in occupancy is observed for CAMTAs during 1-hour treatments with $30 \mu \mathrm{M} \mathrm{CHX}$ at $22^{\circ} \mathrm{C}$ or $0.1 \%$ DMSO at $4^{\circ} \mathrm{C}$ relative to treatments with $0.1 \% \mathrm{DMSO}$ at $22^{\circ} \mathrm{C}$ (mock control) or for CBF2 relative to the wholegenome average during a 4-hour incubation at $4^{\circ} \mathrm{C}$. Red-green shading indicates log2 fold-changes in gene expression after 2 hours with the above $\mathrm{CHX}$ or cold treatments relative to mock controls, for clusters of genes from Figure 2. 


\section{Supplementary Figure 4: $\mathrm{CYHr1}$ seedlings have higher translation}

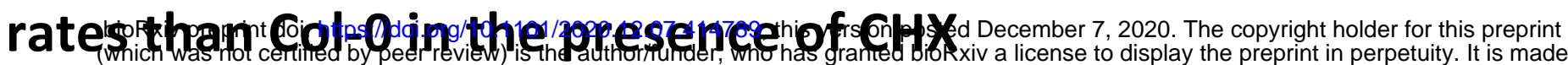
available under aCC-BY-NC-ND 4.0 International license.

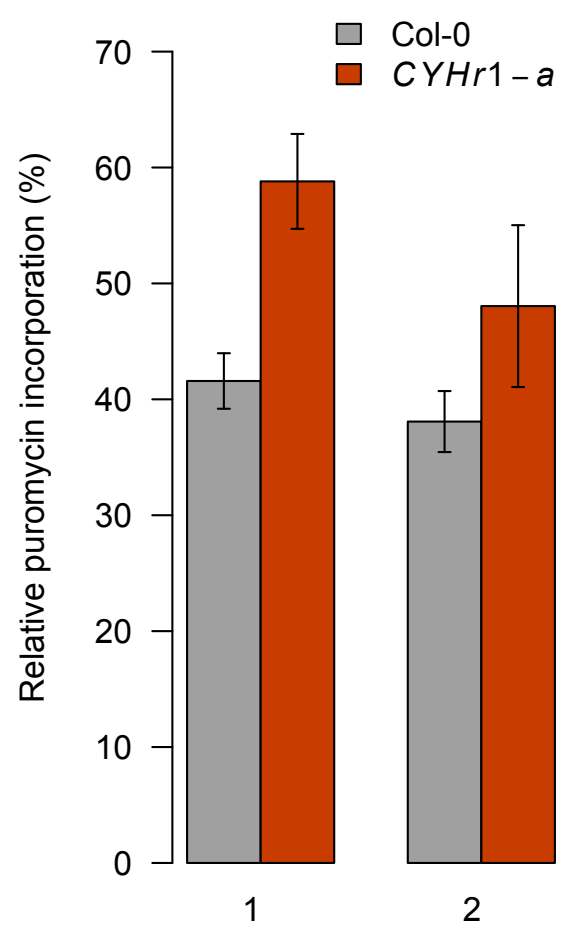

Duration of treatment (hours) 


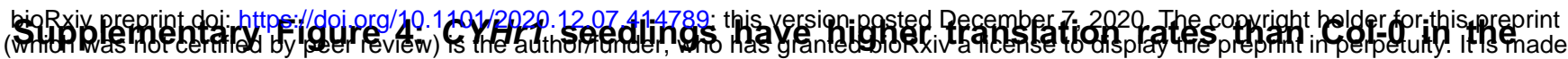
presence of $\mathrm{CHX}$.

Col-0 and $\mathrm{CYHr} 1$ seedlings (line $\mathrm{CYHr} 1-\mathrm{a}$ ) were grown in long days at $22^{\circ} \mathrm{C}$ for 7 days and treated with $30 \mu \mathrm{M} \mathrm{CHX}$ or $0.1 \%$ DMSO (mock) at $22^{\circ} \mathrm{C}$ for 1 or 2 hours, followed by a 30 -minute treatment with $150 \mu \mathrm{M}$ puromycin. The amount of puromycin-labelled proteins was normalised to actin levels and is given for $\mathrm{CHX}$-treated samples relative to mock controls for each time-point. Error bars indicate the standard deviation for 3 biological replicates, with 10 to 15 seedlings per replicate. 


\section{Supplementary Figure 5: Validation of nuclear- and cytosolic-}

$10 \mathrm{Ca}$ available under aCC-BY-NC-ND 4.0 International license.

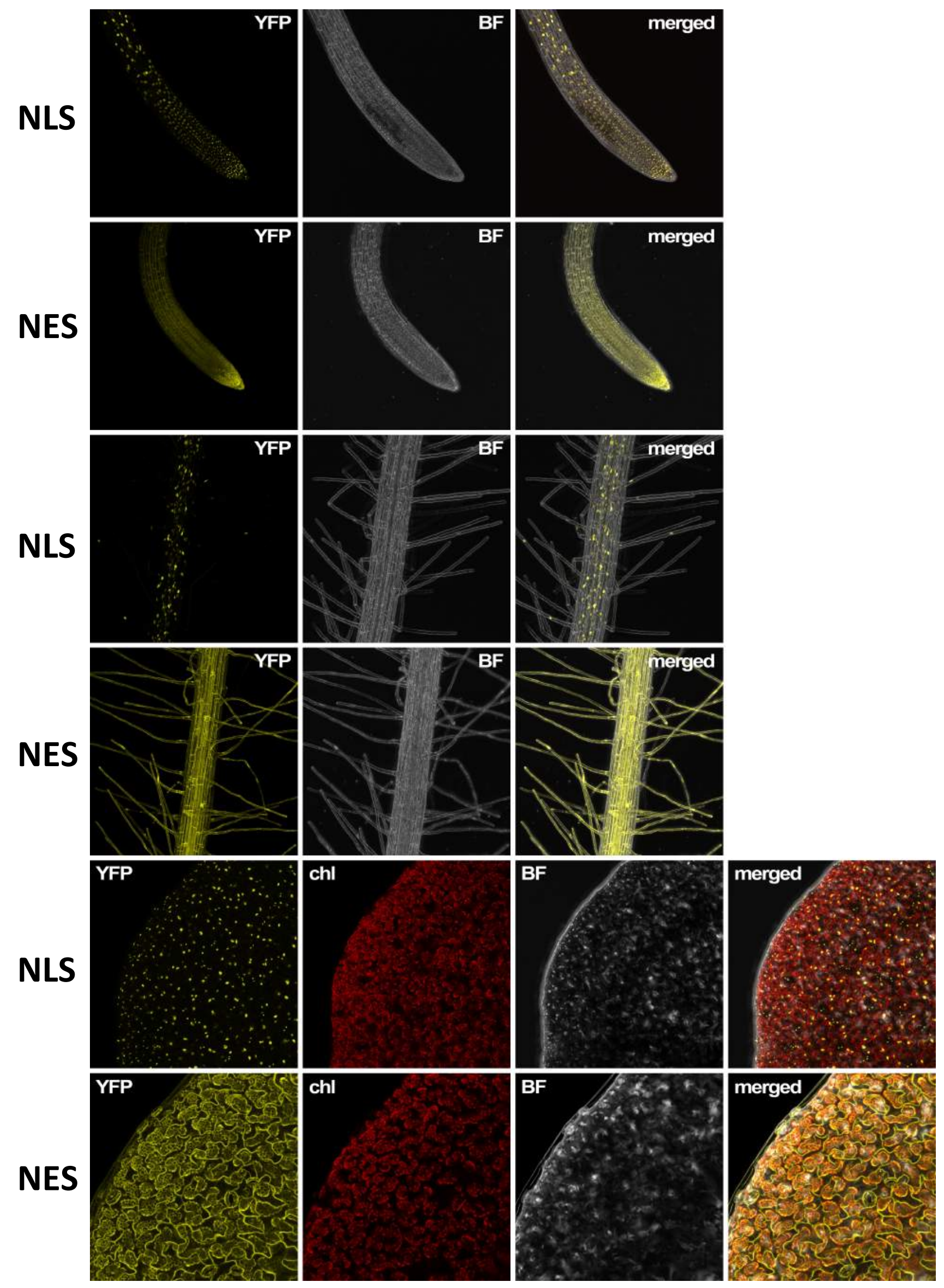




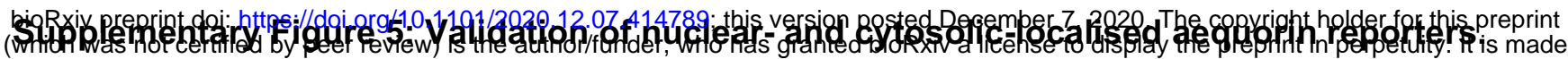
Confocal images of the fluorescent protein Venus (modified yellow fluorescent protein, YFP) in $A$. thaliana Col-0 pUBQ10::NLS SV40::VENUS::APOAEQUORIN (NLS) and pUBQ10::NES $S_{P K 1}::$ VENUS::APOAEQUORIN (NES) roots and cotyledons. Seedlings were grown on agar in long days at $22^{\circ} \mathrm{C}$ for 7 days before imaging. BF: bright field; chl: chlorophyll autofluorescence. 


\section{Supplementary Figure 6: The CHX-induced increase in cytosolic

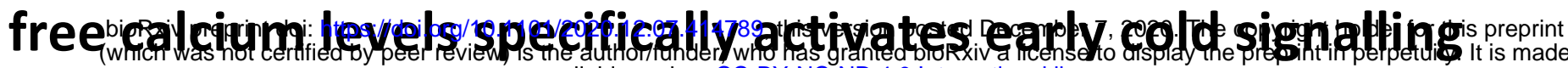

A

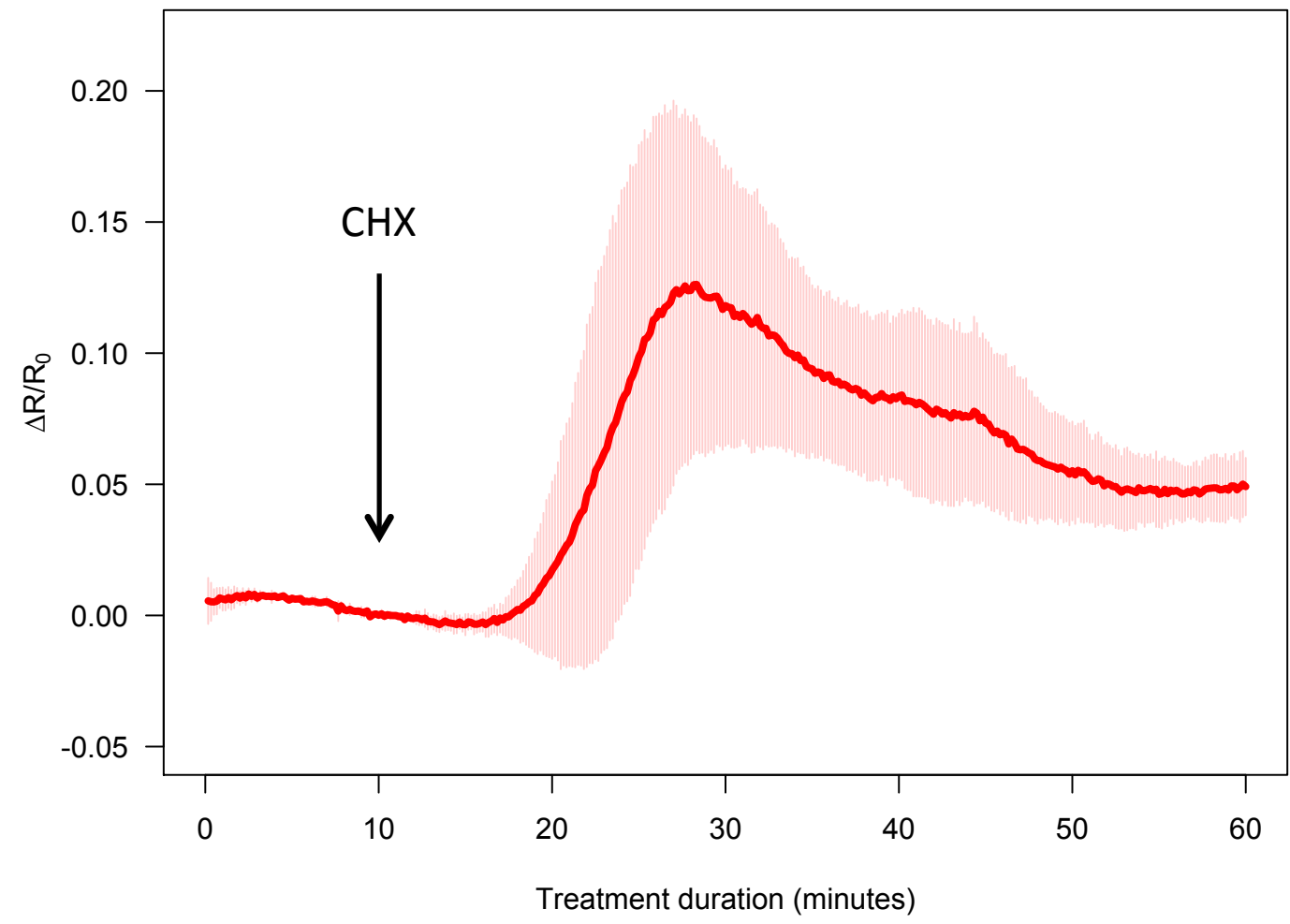

B

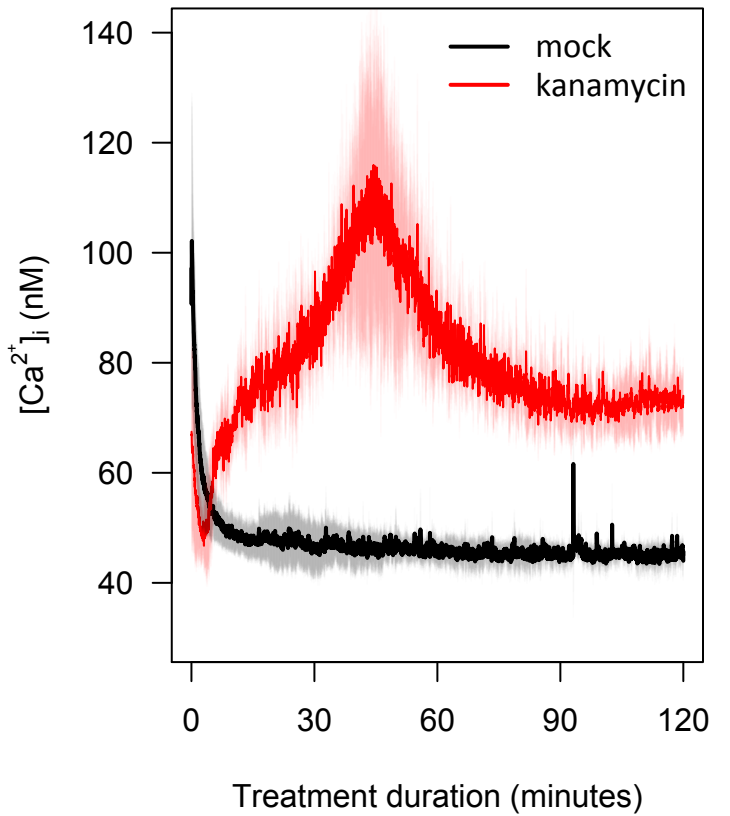

C

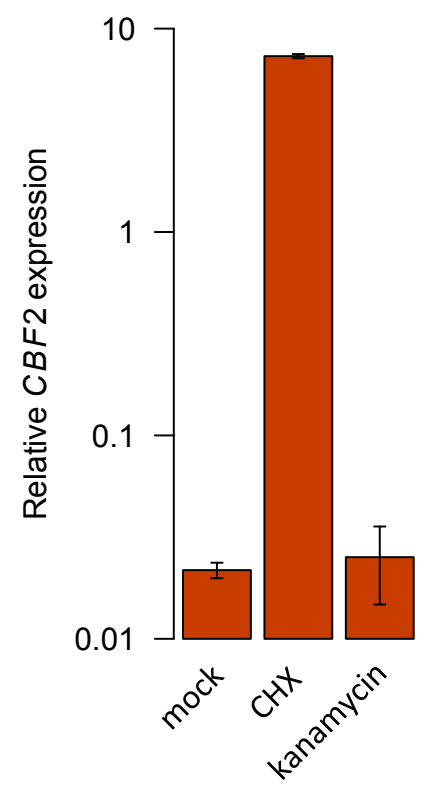




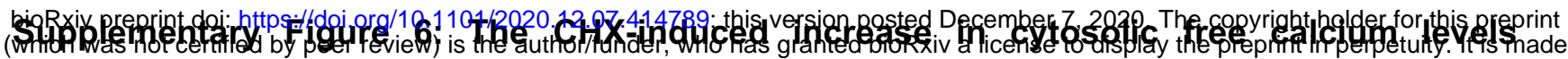
specifically activates early cold signnalling.

A: $\mathrm{CHX}$ induces an increase in cytosolic free calcium, as observed using the FRET-based calcium sensor Yellow Cameleon 3.6. A. thaliana Col-0 pUBQ10-NES::YC3.6 seedlings were grown on halfstrength MS medium at $22^{\circ} \mathrm{C}$ with a 16-hour long-day photoperiod for 7 days and placed in dedicated chambers overlaid with cotton wool soaked in imaging solution. The treatment was carried out by supplementing the imaging solution with $\mathrm{CHX}$ to a final concentration of $30 \mu \mathrm{M}$ after 10 minutes (indicated with an arrow). The FRET cpVenus/CFP ratio $(R)$ was measured over time in root tip meristematic cells and normalised to the initial ratio $\left(R_{0}\right)$. Relative cytosolic free calcium levels, represented by $\Delta R / R_{0}$ values, are given for 3 individual seedlings, with error bars indicating standard deviations. B: The $70 S$ translation inhibitor kanamycin triggers an increase in intracellular calcium levels. A. thaliana Col-0 pCaMV35S::APOAEQUORIN seedlings were grown in liquid culture at $20^{\circ} \mathrm{C}$ with a 12-hour photoperiod for 8 to 12 days and intracellular free calcium levels were quantified luminometrically during 2-hour treatments with $30 \mu \mathrm{M}$ kanamycin or $0.1 \%$ DMSO (mock). Cuvettes were placed in the luminometer immediately after the addition of chemicals. Shading indicates the standard deviation for at least 3 biological replicates, each comprising a cuvette with 3 seedlings. C: Kanamycin does not induce CBF2 expression. A. thaliana Col-0 seedlings were grown in liquid culture in long days at $22^{\circ} \mathrm{C}$ for 7 days and treated with $30 \mu \mathrm{M}$ kanamycin, $30 \mu \mathrm{M} \mathrm{CHX}$ or $0.1 \%$ DMSO (mock) at $22^{\circ} \mathrm{C}$ for 2 hours. CBF2 expression was measured by quantitative PCR and normalised to transcript levels of $P P 2 A$ and $U B C 21$. Error bars indicate the standard deviation for 3 biological replicates, with 10 to 15 seedlings per replicate. 


\section{Supplementary Movie}

bioRxiv preprint doi: https://doi.org/10.1101/2020.12.07.414789; this version posted December 7, 2020. The copyright holder for this preprint (which was not certified by peer review) is the author/funder, who has granted bioRxiv a license to display the preprint in perpetuity. It is made available under aCC-BY-NC-ND 4.0 International license.

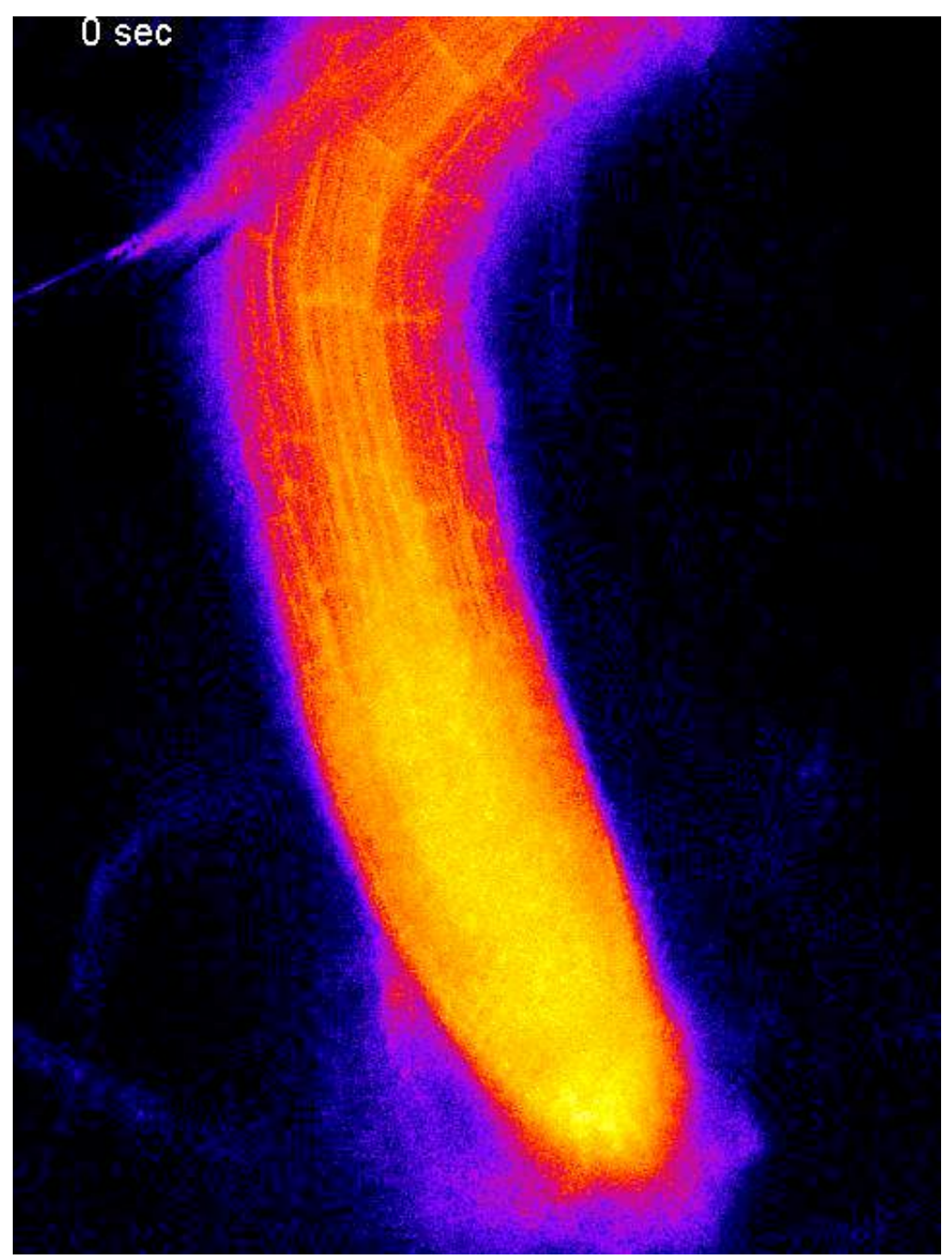




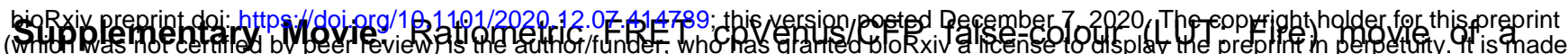

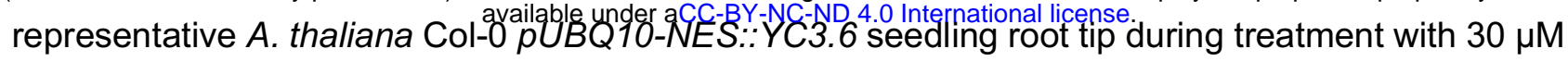
CHX treatment, from Supp. Fig. 6 A. 